加排 $ル$ 臟 $>1 二$ 減急 ス泄・神少然少性 N量尿經事しルス腹 $\therefore$ 量 $\exists \exists$ 化 腎增 切犬物

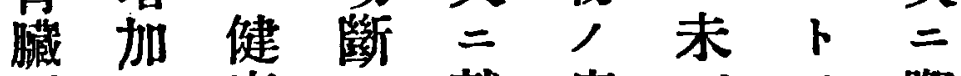
尿 $入$ 康 $入$ 就病 管 ○側ルテ的人ルシ , 著 $\exists$ 實排人, 屢

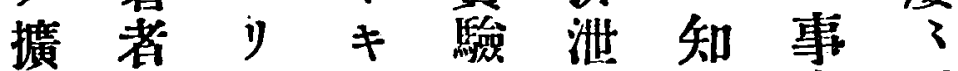
張 $心$ 的占今實 尿 $\exists$ 這增・文ザナ中

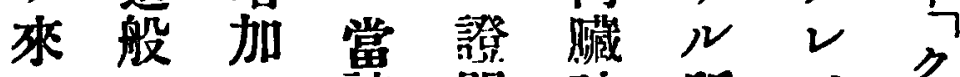
タ人 シ該明神所ドク

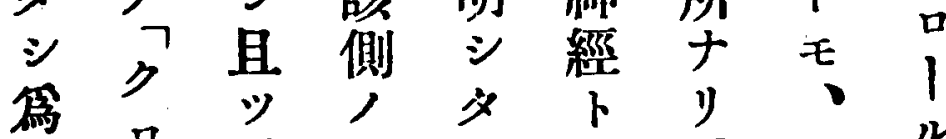
馬口尿腎り， ○其 ハ 掔吊臟。間著果华

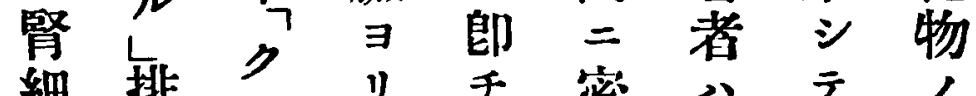
細排りリチ密、テ忩 胞 泄 1 排一接此何排 , 量, 泄侧, ᄀ, 泄苍

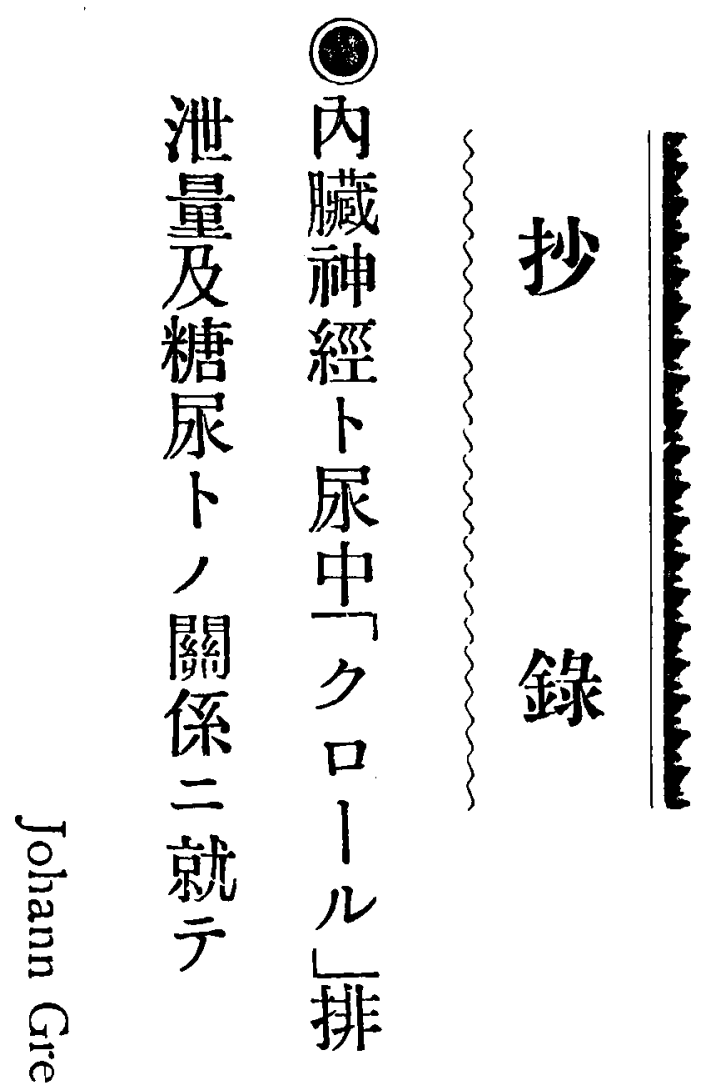

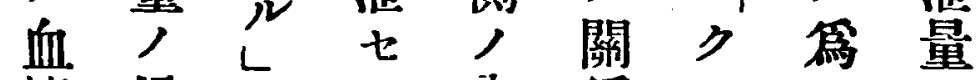
液增,

$\exists$ 或 7 臟 火

只形麻傷

卜赫成 瘁 死

ス血ジ，

儿球 テ y 畺

人, 腺卜 相

分性 学

り解臟、术

○器 或 ダ

文不永制

多 号損 赤 然

原学害血 せ

發

性 招, 。

炎 致 艿 或

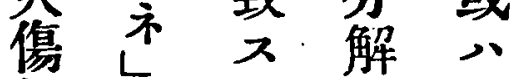

組,ル二血

織 形 $=\exists$ 液

人成昰当過

附 $\exists$ 硝熟出

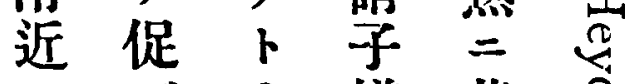

二ガナ㳟 基

續 ス シ 血 ク

發 二 、栓 心
总ミ撗ノ不血濾

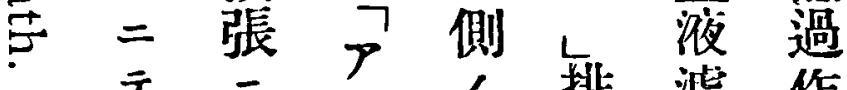

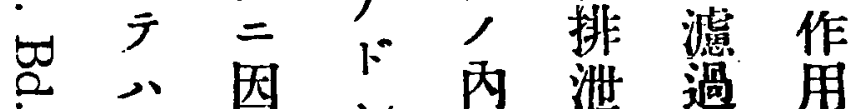

此不 $v$ 淔過用

火 @ 此 ルナ唐藏量莋角

怘尿モ! 經減, 進

死 $\exists, 1, \exists \pi$

ノ $\quad$ 。 惹 = レ 感 ご退ル

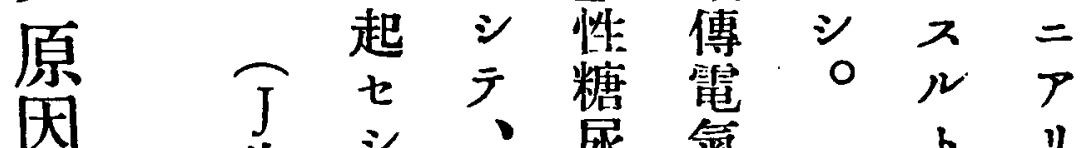

生、尿氣载

二 生么單 $\ni=$ ₹

就 抄 $ル$ 誘 テ

テ

$\exists$ 内铲刺

得臟 ス 韩 恐。

ズ 神 0 ス

$\circ$ 經之ル

\

切副 キ

$\therefore$ ス血、

悉管 雨

亏 故

$\eta$ 百

丞之

$\neg=$

ク 反

à 


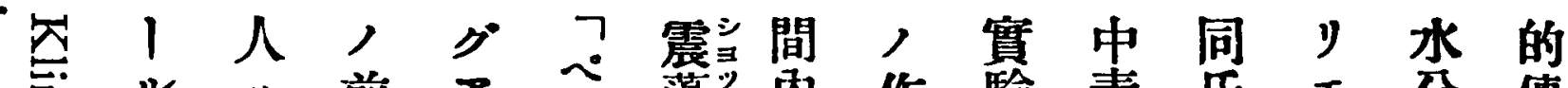

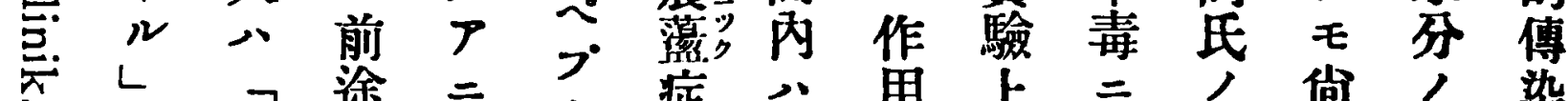
石 $>$ 途 $=$ 症何用上二，倘， 染

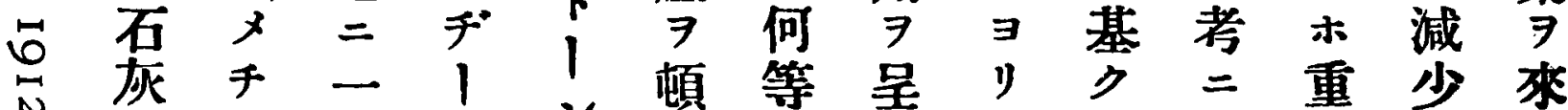

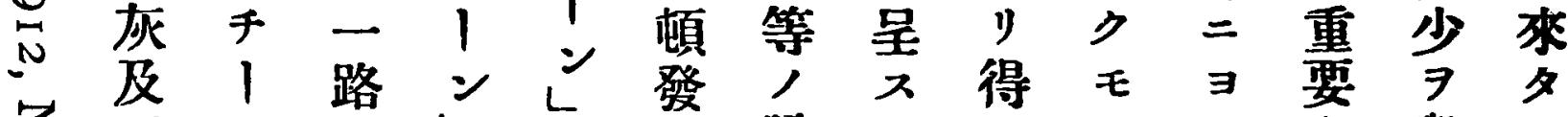
只光次,

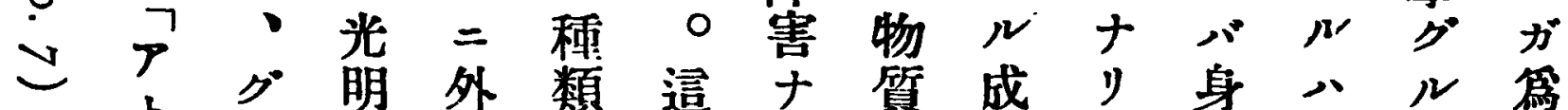
卜 ク琞外類這ナ質成り身へル篇 J 生、ヂフザ七瑇過二ヨ 抄ンジルル゙

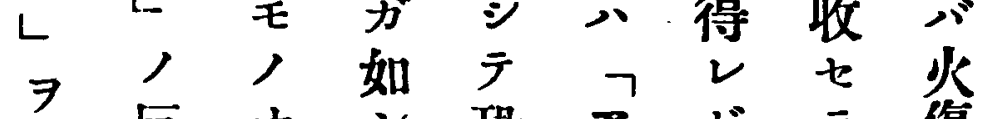
知扰ナ染恐卡ドラ 傷 ハ藥○此クブ逐、際

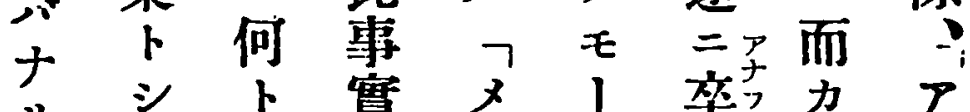

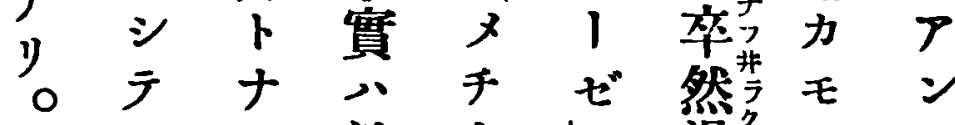

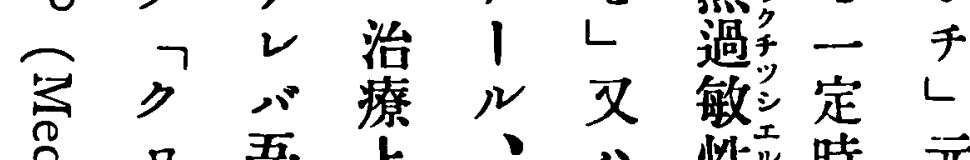
邑口吾上、八性公時 元

泉フリり 質 70 忽 1 然 , 氏 $ト$ 或 際, 二 觀 以 生察上鹪 ルリ諸 $\exists$ 產卜學 物 ス 說 體 $\exists$ 内

著用的七部, 八性何用疹七學 者二效 シ 八實多 7 ス 型 , 相 果 = 喘驗數減ナル 示遇 $\exists$ 二息成, 退レ卜外或從 七七收例樣 績經七バキナ八へ ルザメ $\rightarrow$ 病二噞 シ フ 處り得除態 $\exists$ 家 方 $\neq$ 夕多

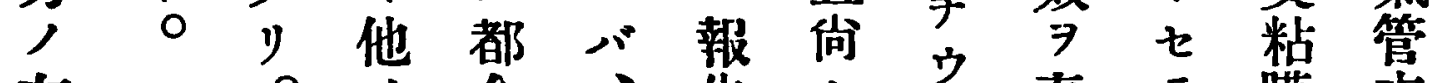
左 0 合、告水公奏ラ膜变

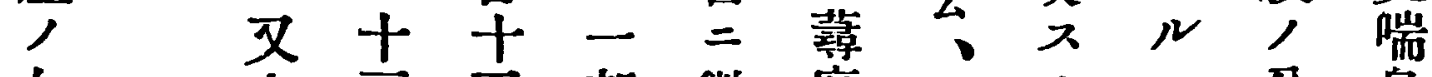
如本三五 部徵磨、ル、分息 シ 剂例 例 八

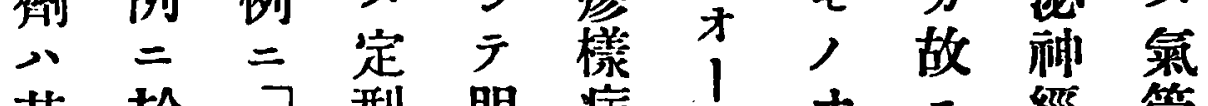

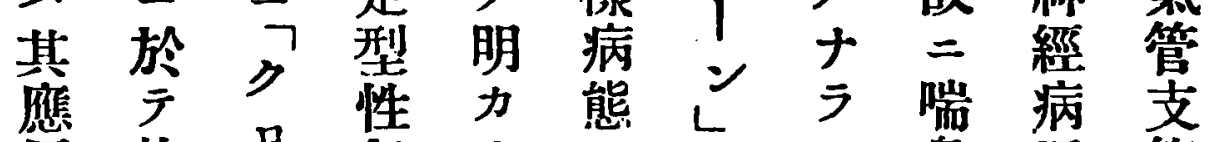

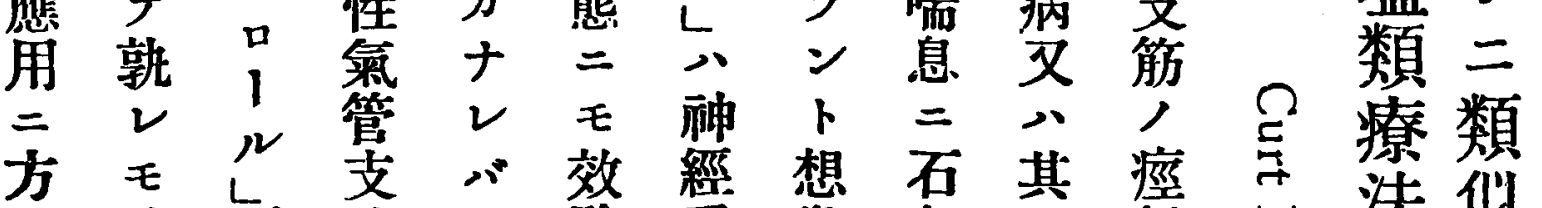

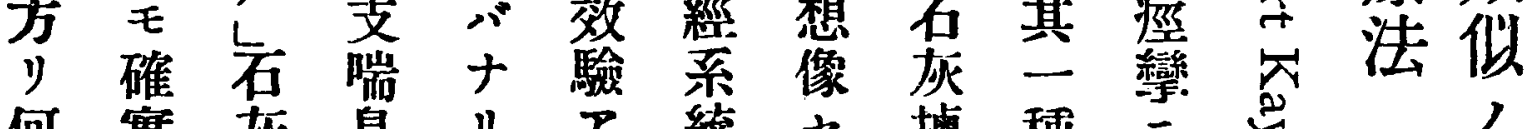

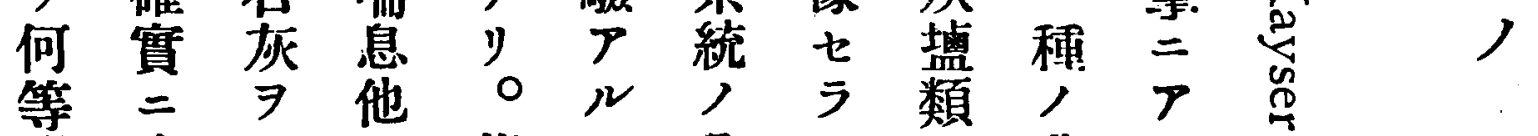
病氣 症管 二支 對喘 ス息 ル 站 石 二 灰之 壚 $v$ 類

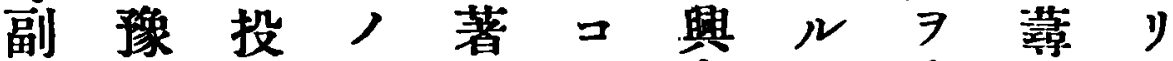

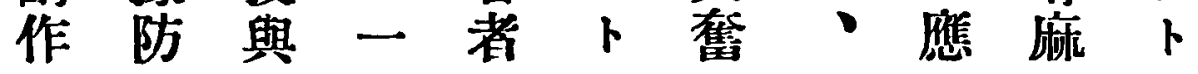


號 二十七百二第

ンリ血

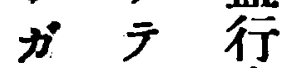

第モ 內

$x$ 發 $=$

著 熱 於

者 現 テ

八像 化

$7 \Rightarrow$ 學

八招 的

ᄀ 入 戟

$1^{\#} N=$

事因

ᄂ $>$ ラ

, $2 x$

微ヤ純

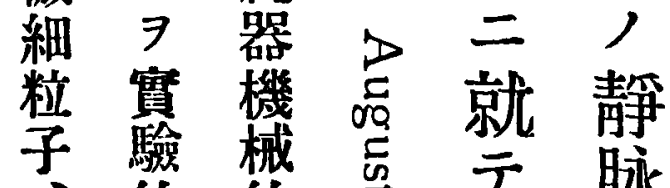

、的的

其 二 刺

他證戟 只

廖明二

二 用

$\exists$ ヨ

ルル

發 微

莌細

現 粒

象 子

內
亏隶 刺

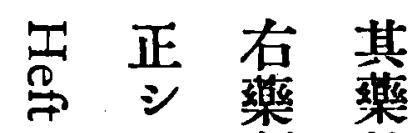

心 劑 效

服, 作

注無莏飾用有

射作先實分藥整

樣 飞 $\exists$
行 八 劑 時

七日應 一

輫角 食

么 持 後 题

へ續 宛

シ ス 普: シ テ

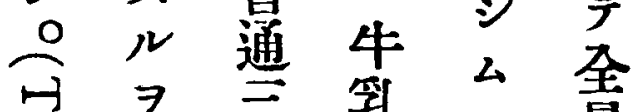

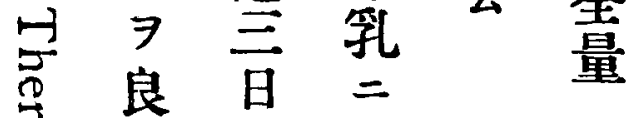

間和

字 シ 7 經

其学 角

占規 則
蒸 單 ク

锴

水 舍 ル

石

灰

$=7$

$\Omega$

?

四

○四三

$\because 00$

$\dot{\circ} \dot{\circ} \dot{0}$

$\widehat{乃}=$ 赤モ象皆以り棈口金

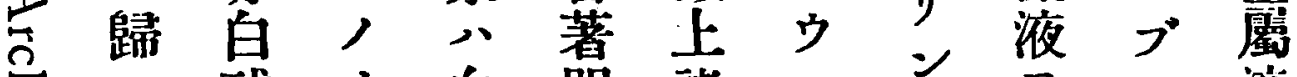

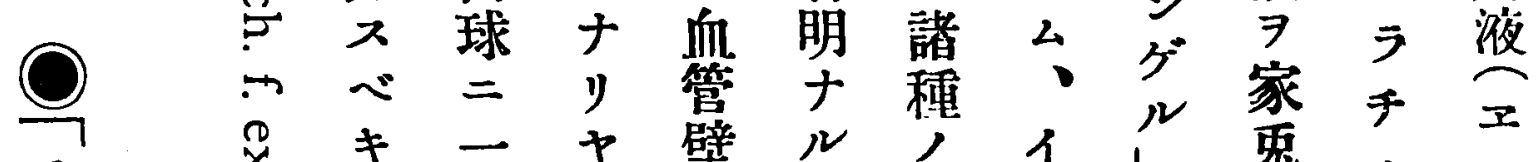

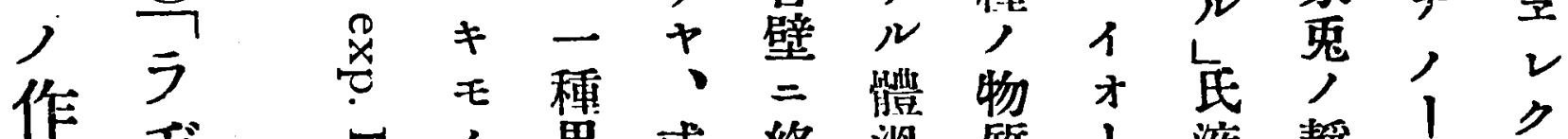

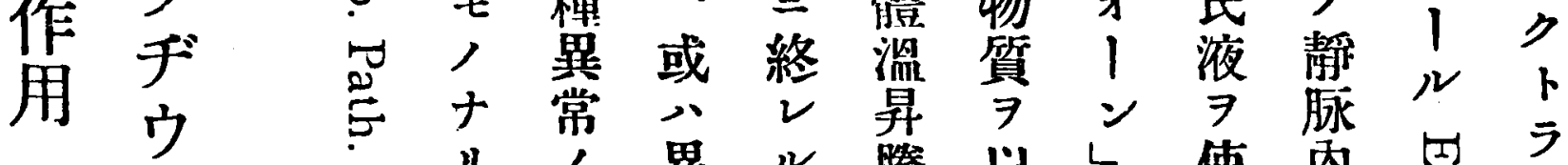

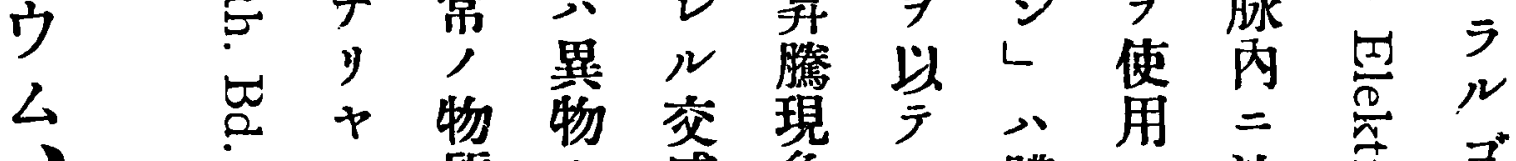

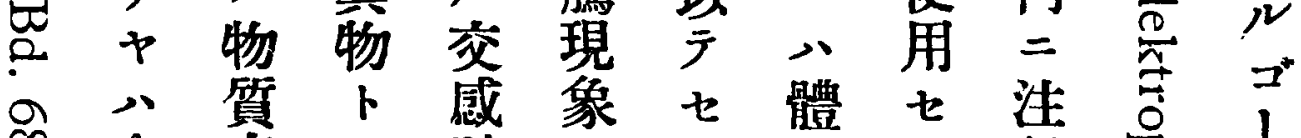

9 今缶

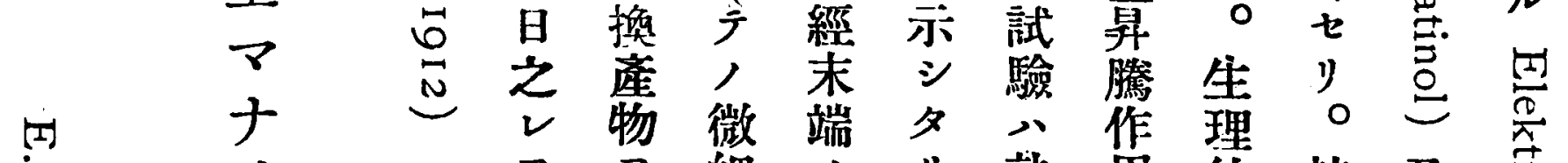

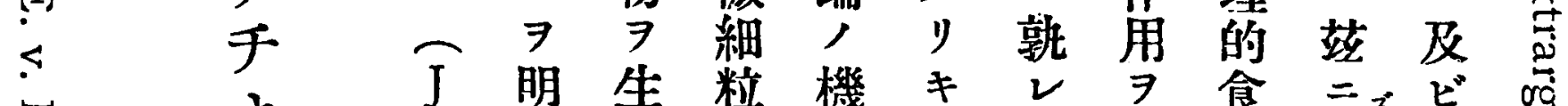

矛

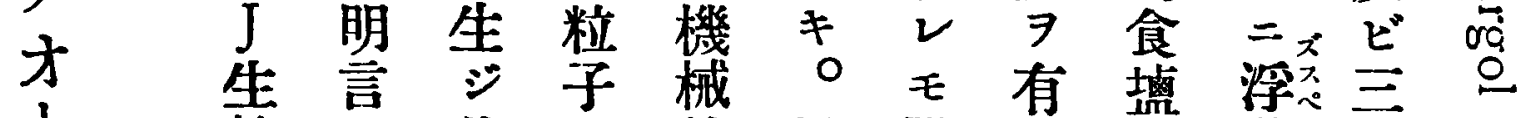

抄入其, 的但陽入水游硫及 ル作刺刺シ 性レ中人化

$\exists$ 用戟戟這 $=$, 目砒

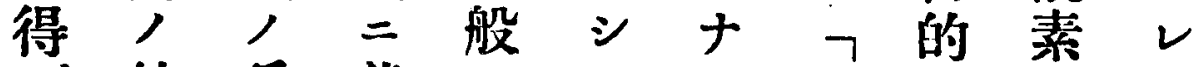

ズ 結 第基方 
57 號 二十七百二第

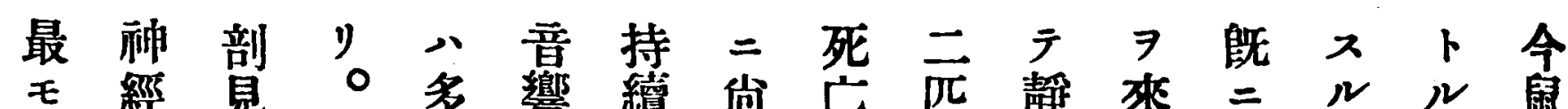
微 系所

二統 見

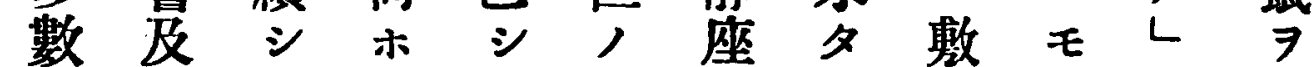

、 $=$ r

政 於 シ

髓 テ テ

八 小

之此 圣

充 藏

二 血 器

次 特 殊

$\neq=$ 二

、高 肺

大度,

腦二充

皮 シ 血.

矮 テ

啝

最雅 夕

主中

高小。

展 腦 中

名 夕

五、鼠

試捻り旦他中只 0 間 $一$ 空 $x$

驗 撚。間, 小外十ノ = 氣下

～刺又生大ナ乘三後容中十

区戟動存ナルノ時三ル三チ

二八 樞

得二物七皇

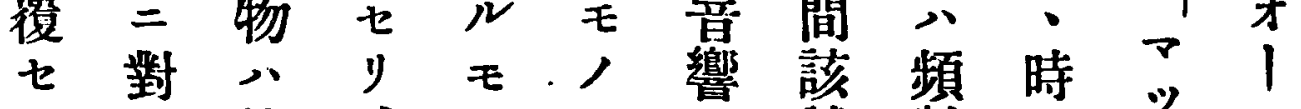

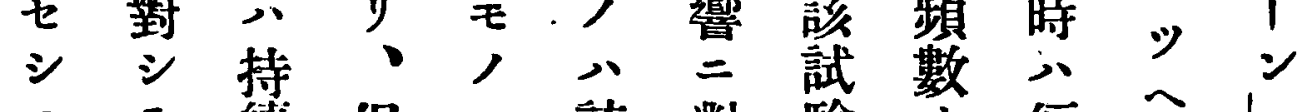

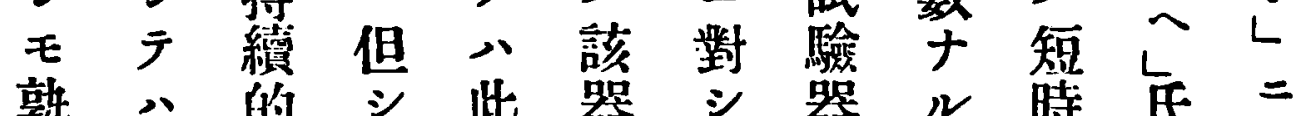

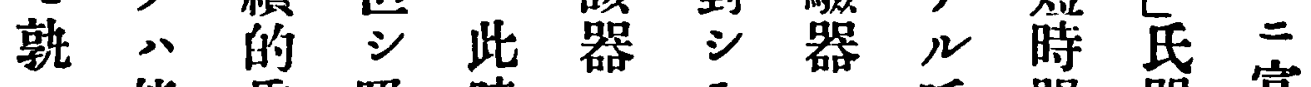

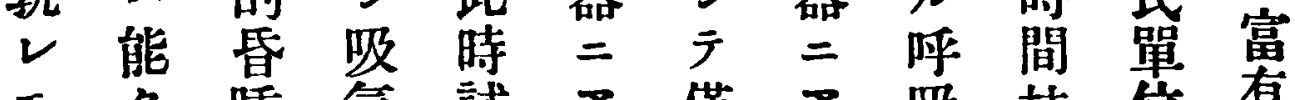

モ刀睡 氣試 $>$ 僅 $\Gamma$ 吸持位有

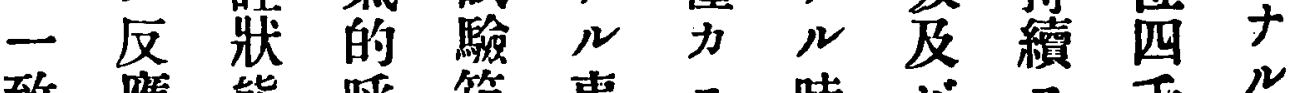

致 碓 態呼箱 事二時 ビ ス 千

人

成り陷困り十㟲鼠氣興至氣 績 $0 y y$ 難 取時

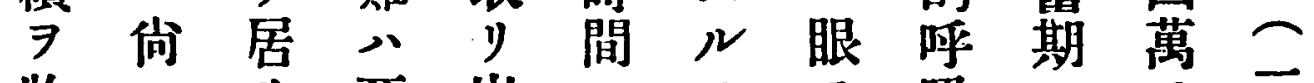
收 $ホ y$ 死出 $=$, 7 吸 $=7$ ᄀ 女著 $シ$ 期七シ シ 閉困次含り

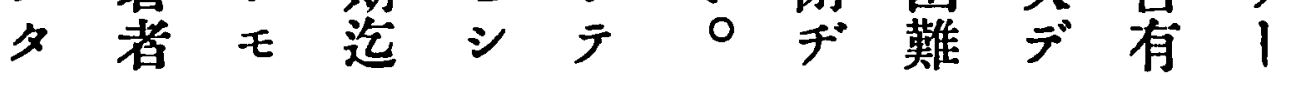

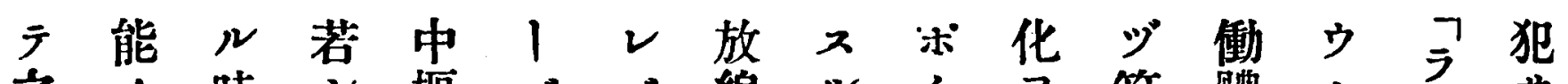

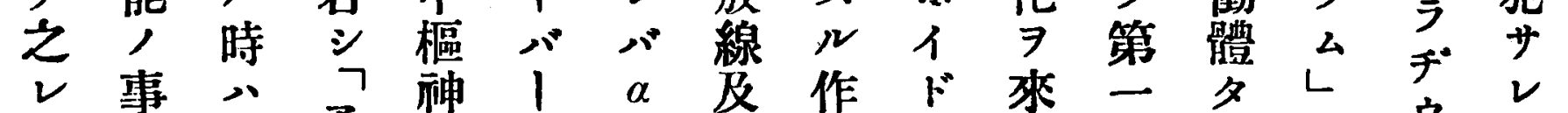

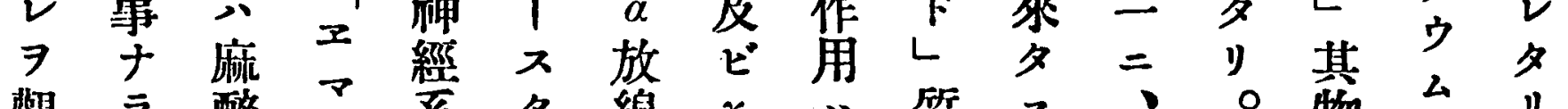

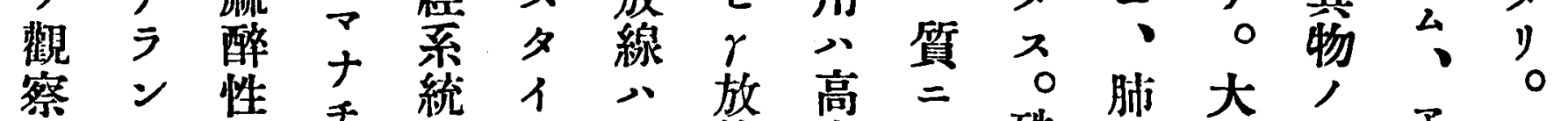

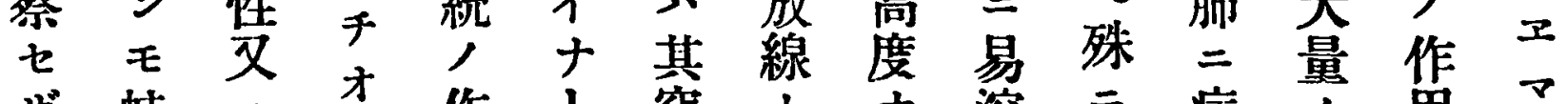

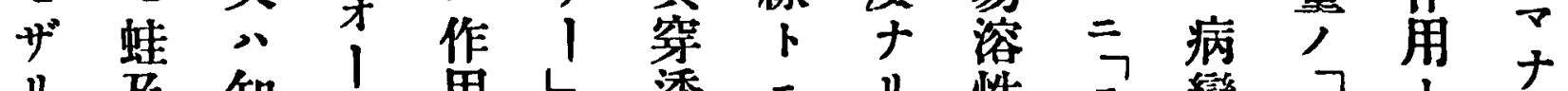

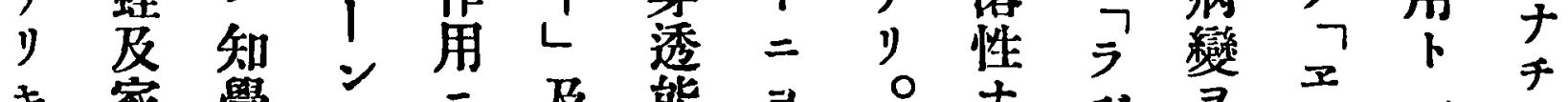
キ 家 覺 L

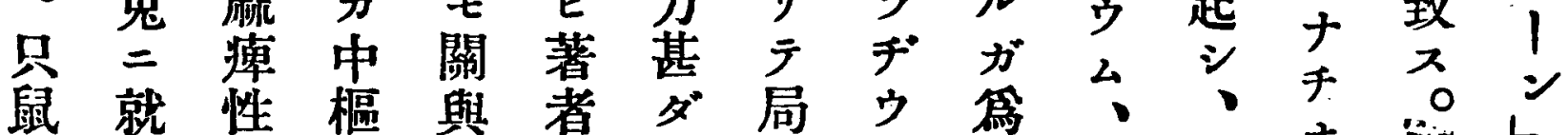

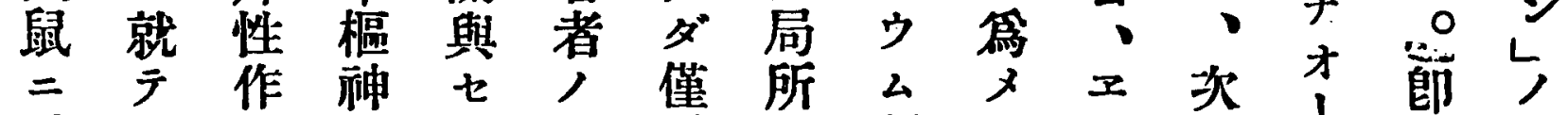

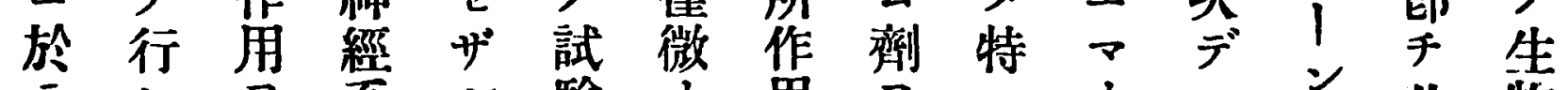

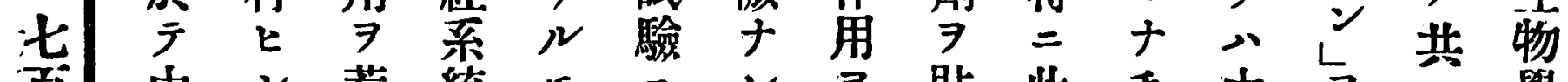

百 中 三樞多起二,

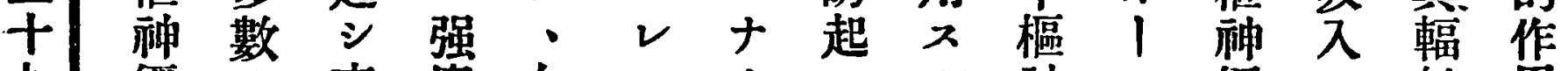
九 經 人 來度 如心゙等 系實 $心=$ シ $\alpha$ ○ 0 時 經 ᄂ 系 ル 放

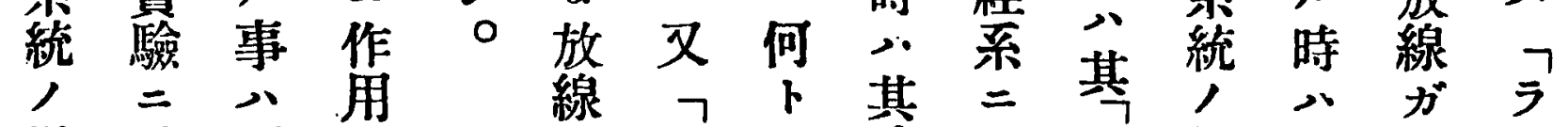
損於 可ス メオ オ 


\section{號 二十七百二第}

\begin{tabular}{|c|c|c|c|c|c|c|c|c|c|c|c|c|c|c|c|}
\hline 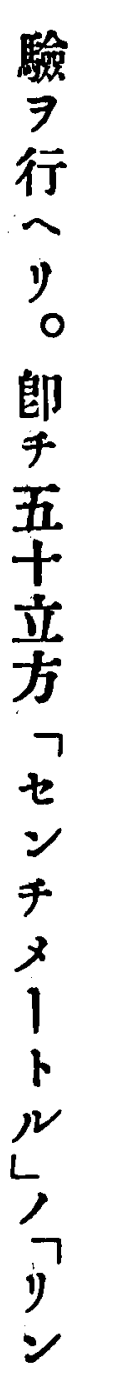 & 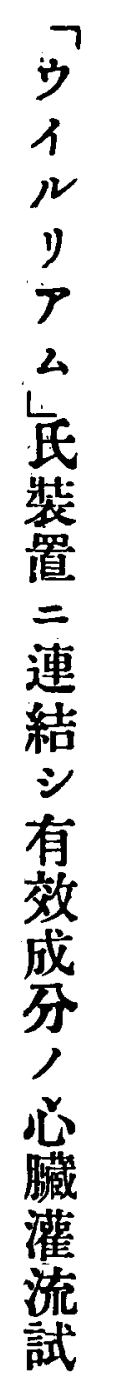 & 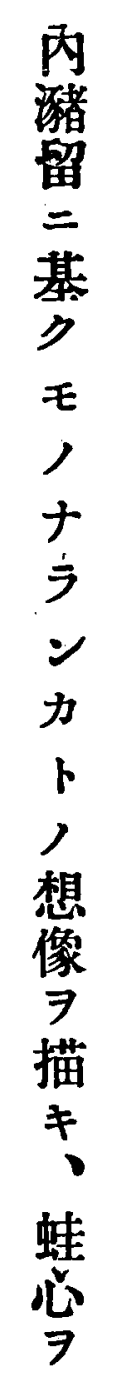 & 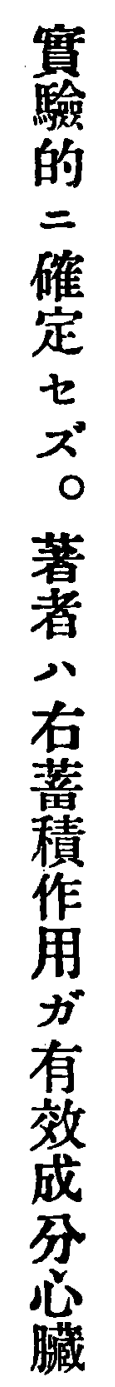 & 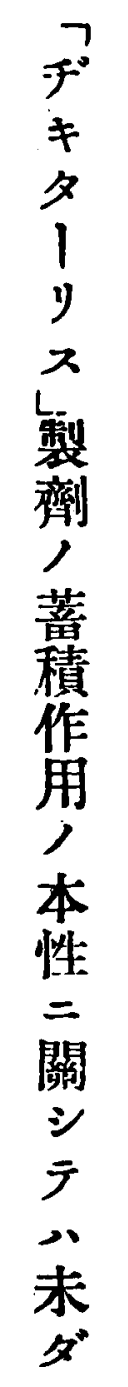 & 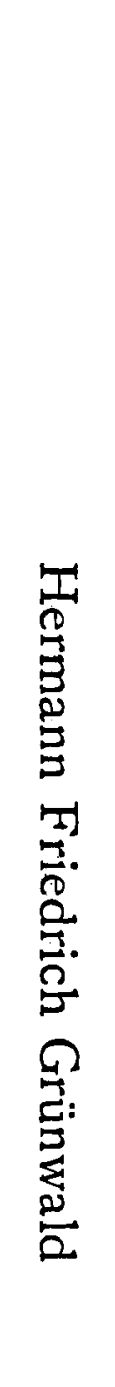 & $\begin{array}{c}\text { 心 } \\
\text { 臟 } \\
\text { 内 } \\
\text { 三 } \\
\text { 渚 } \\
\text { 留 } \\
\text { セ } \\
\text { ラ } \\
\text { ル } \\
\text { ヤ }\end{array}$ & 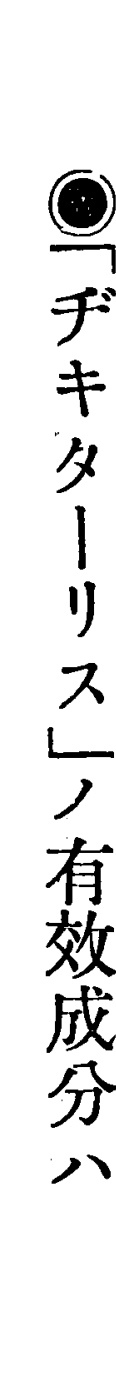 & & $\begin{array}{l}\widehat{J} \\
\text { 生 } \\
\text { 抄 }\end{array}$ & 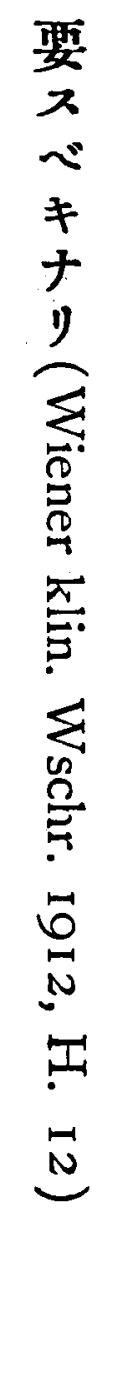 & 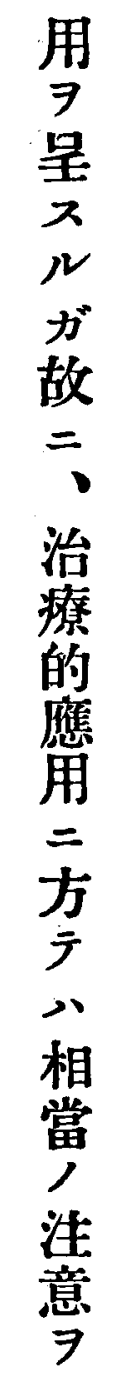 & 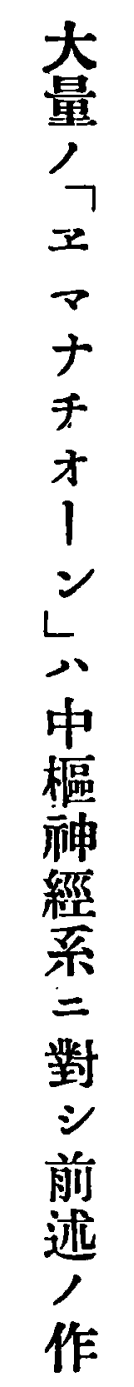 & 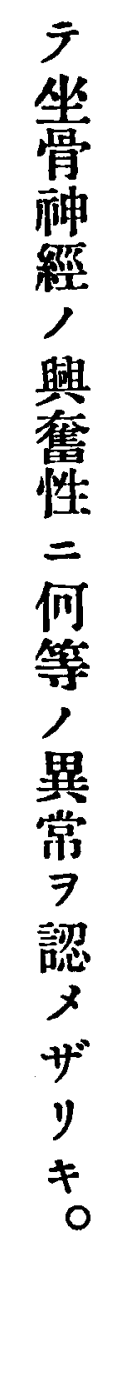 & 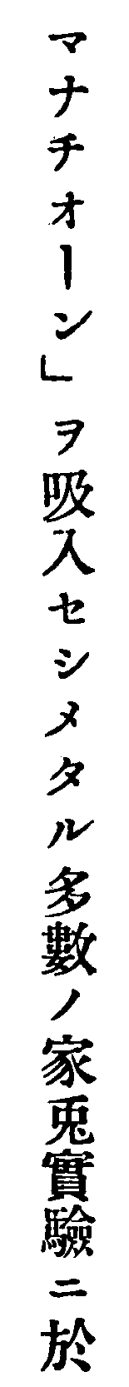 & 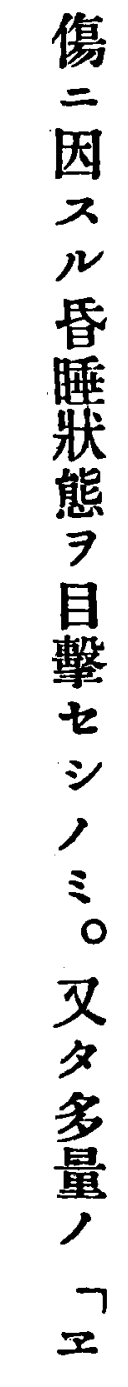 \\
\hline 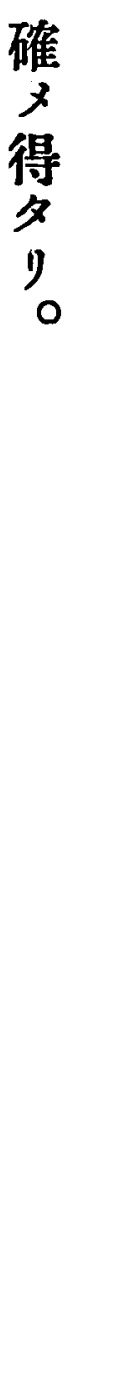 & 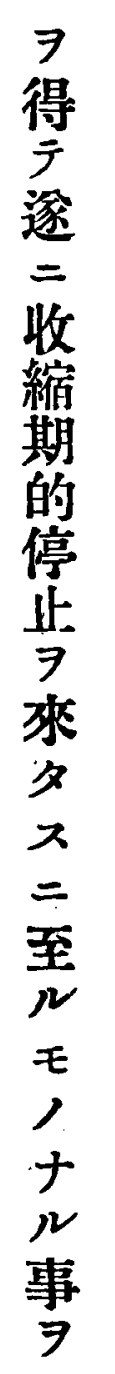 & 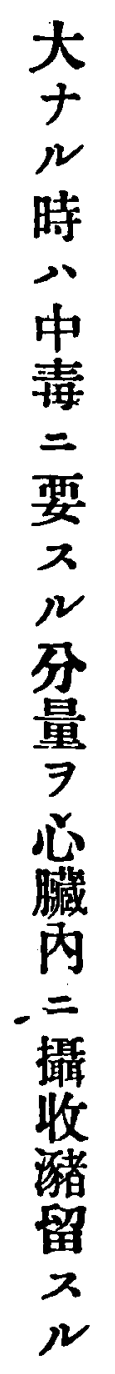 & 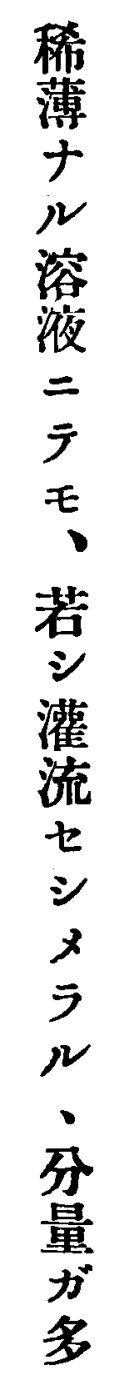 & 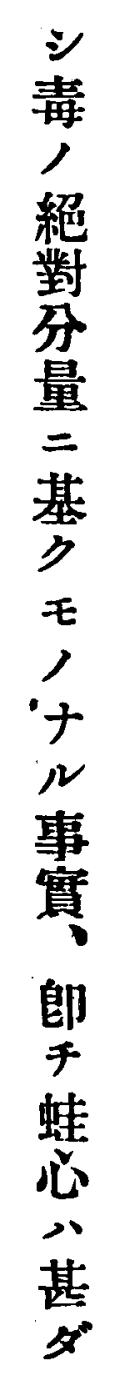 & 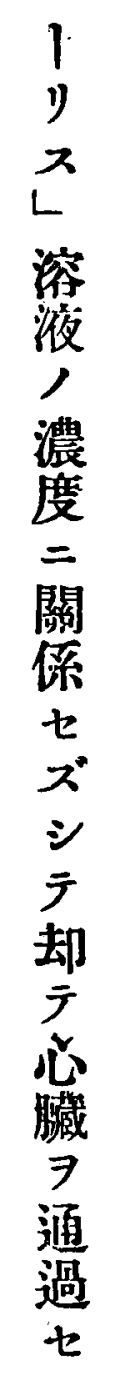 & 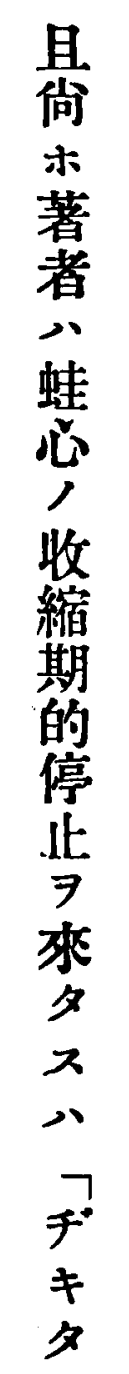 & 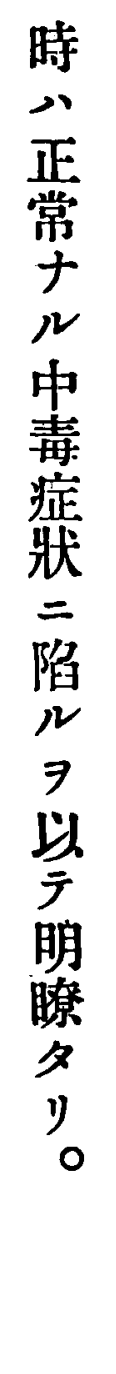 & 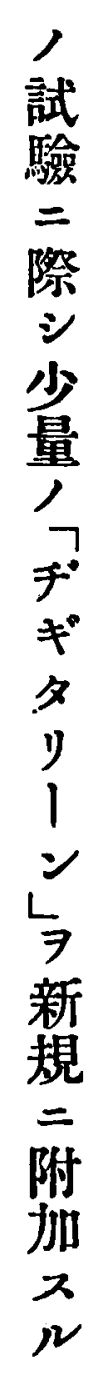 & 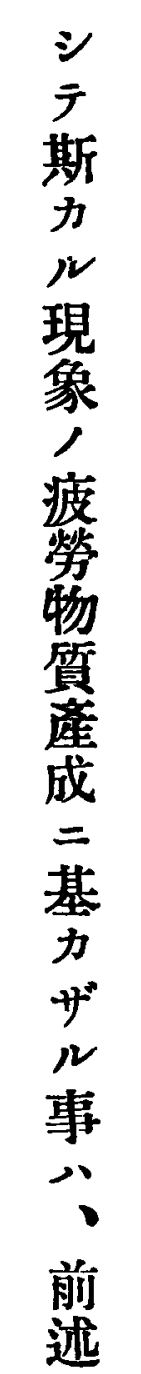 & 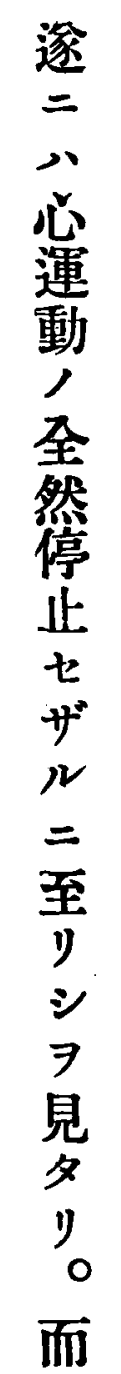 & 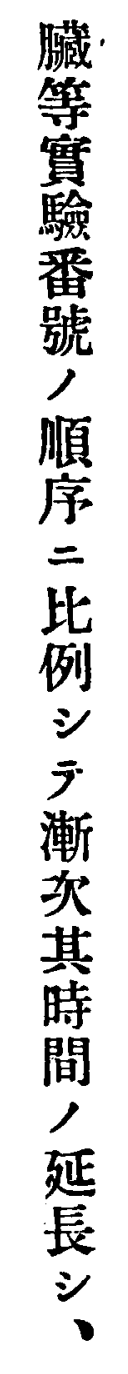 & 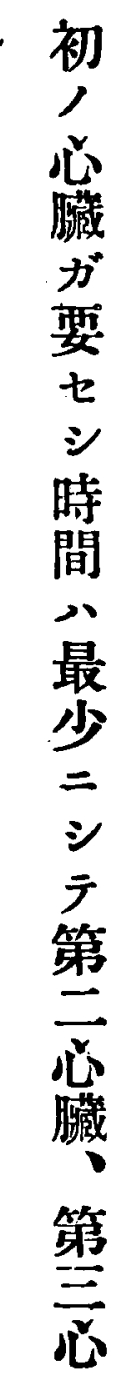 & 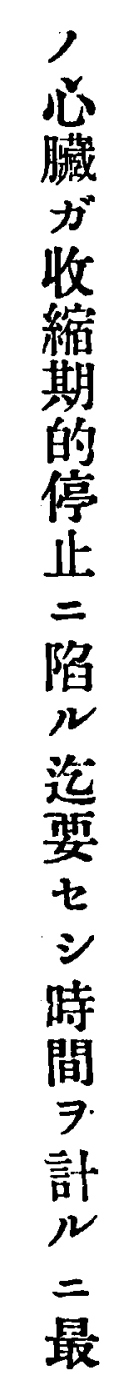 & 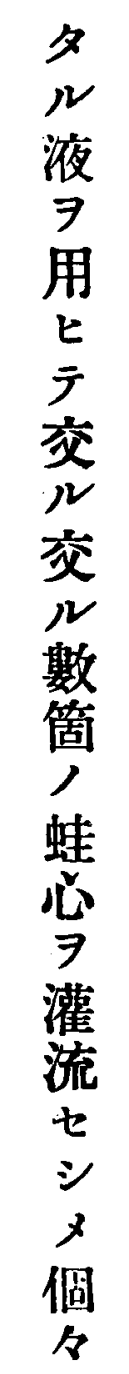 & 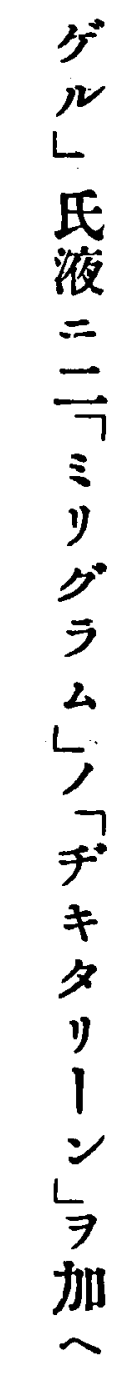 \\
\hline
\end{tabular}


號 二十七 百 二 第

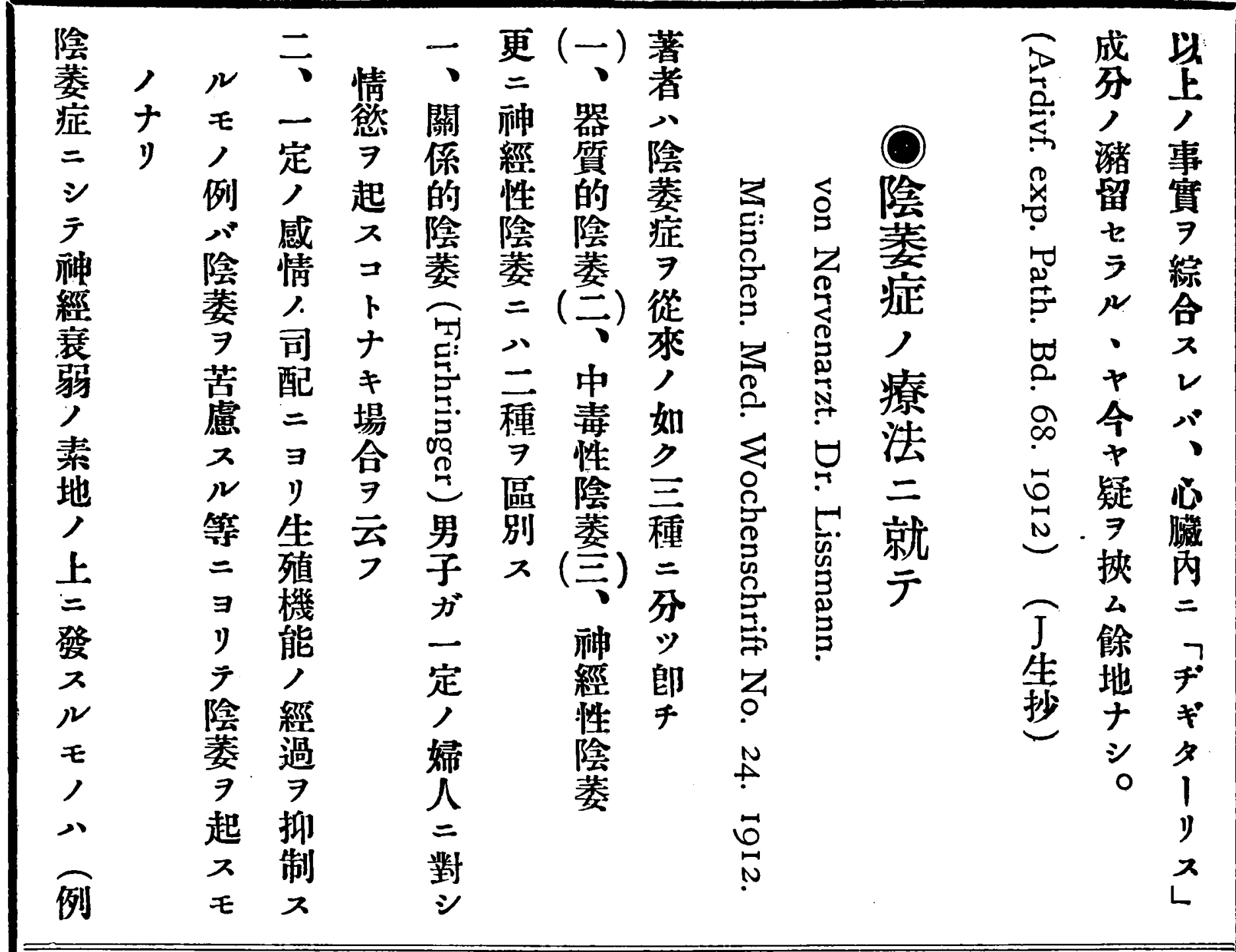

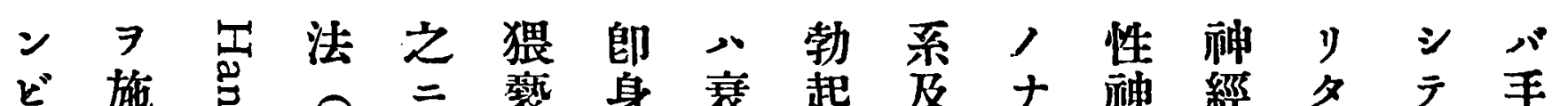
ビ施嵒○三檴身裹起及ナ神經夕テ手

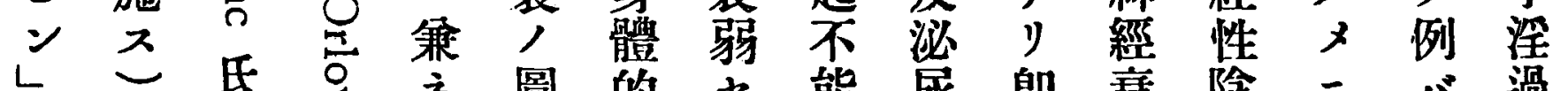
ᄂ 一 氏 市圖的七能尿郎衰陰二心゙過

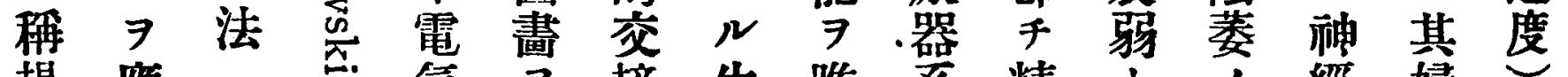

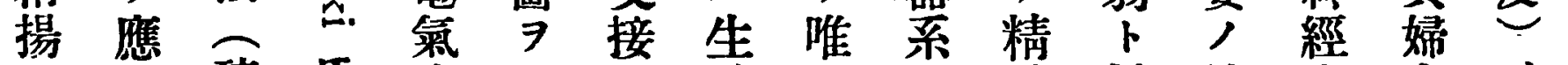
七角碎 氏療見八殖—“神異第衰人神

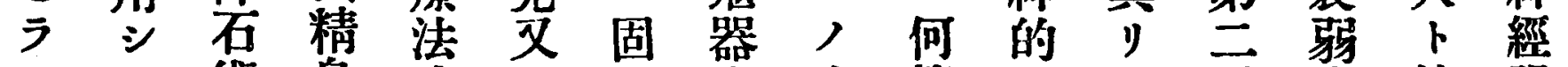
ル 術阜泠 $ヨ$ 中症等二テ種症情强 可用腐水淫》榀候, 勃原八 ナ人蝕療猥 精 $\exists$ 病起發交發滿藥

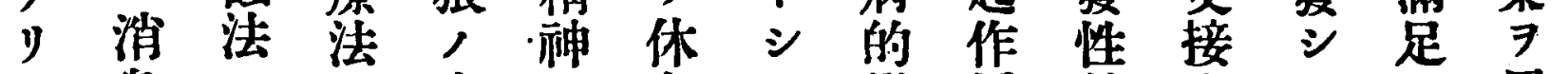

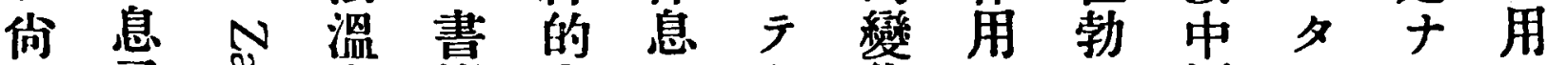
藥子总水籍 萃七發化 $\ni$ 起樞 ルラフ

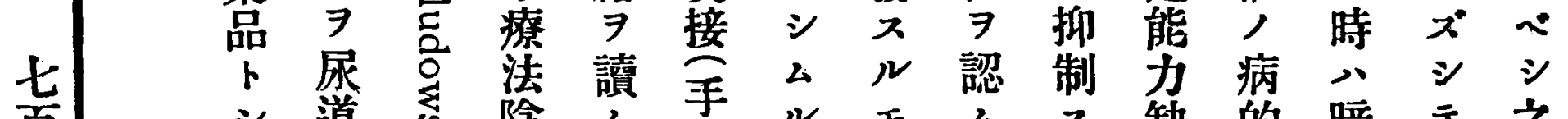

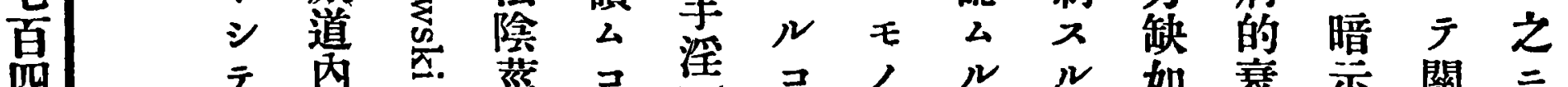

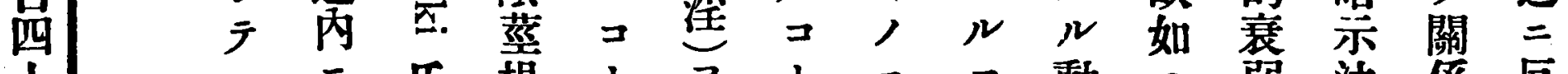

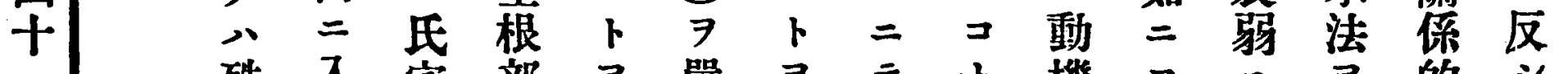
殊 入空部 7 嚴 7 厂 機 $\exists=7$ 的

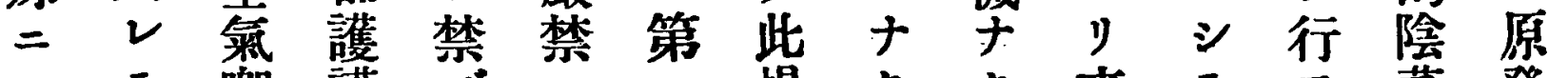
ᄀテ 唧 謨 ズ ス 一場クク來 テフ 萎 發

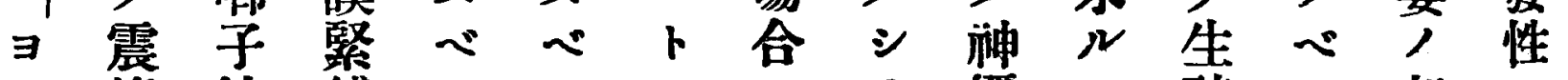
七 搖 法 縛 シ シ ス 


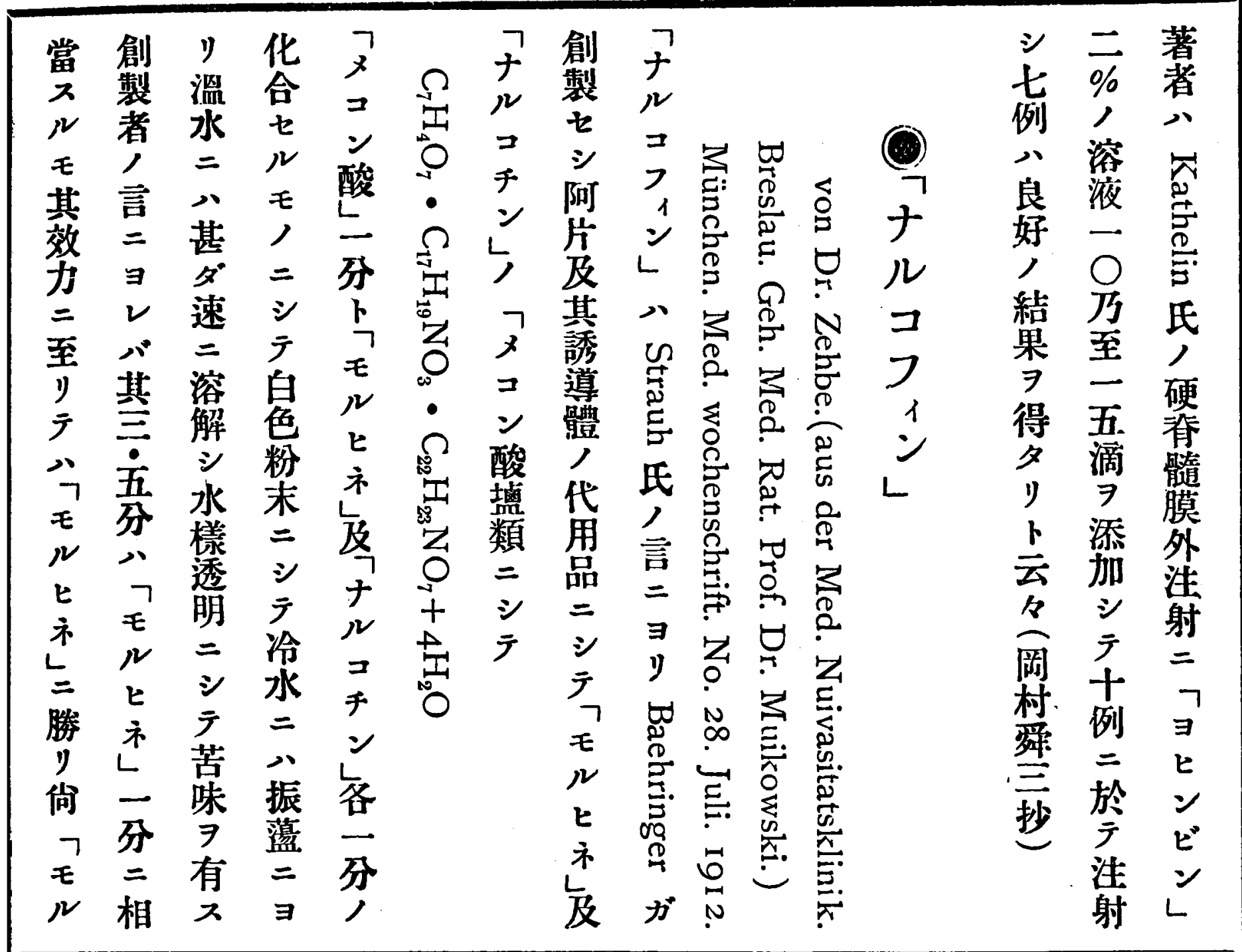

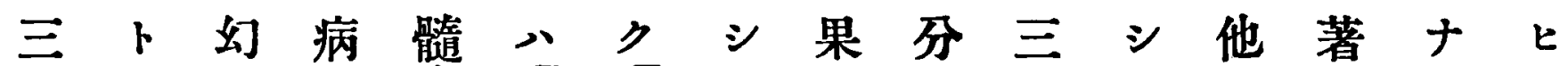

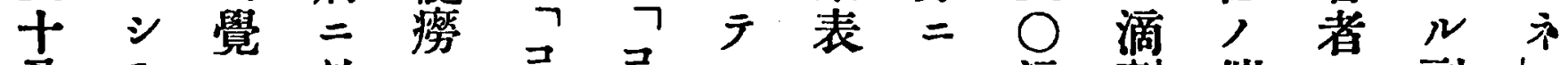

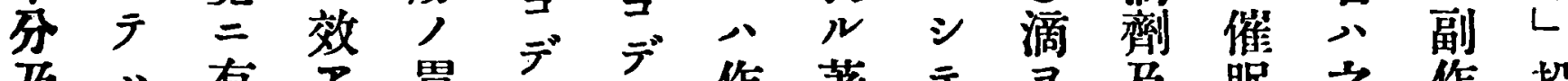
乃心有学胃デテ作著テ タ及眠之作投 至原效り症ンイン.角著效用皮藥方用藥

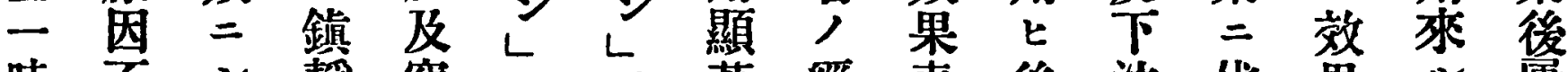

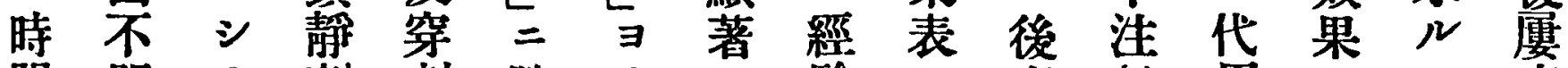
間 明 テ 劑 刺勝り 二 噞 $v$ 者射用 $\exists \geq$ 乘

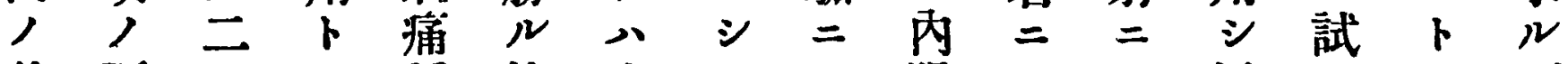

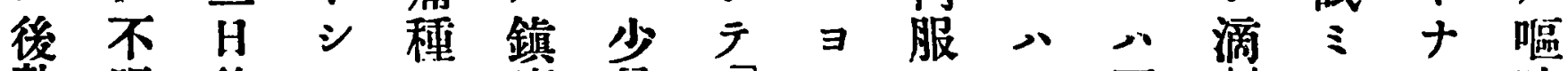

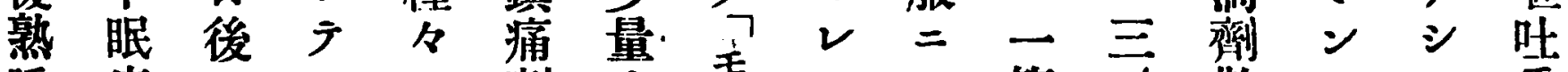
睡 症三八ノ劑 ナ

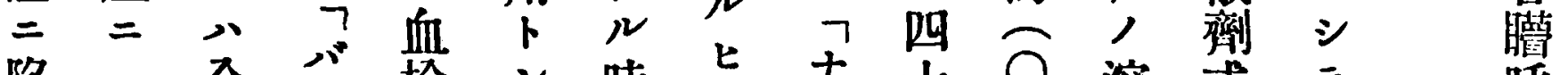

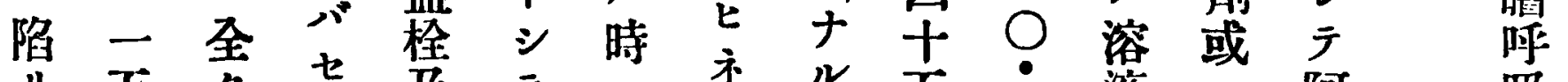

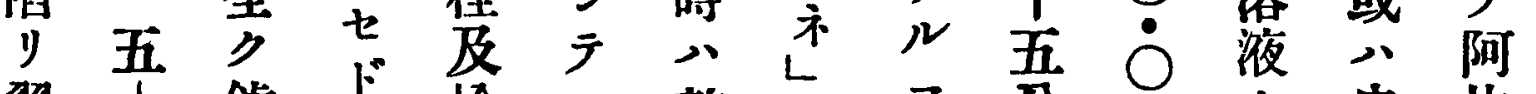

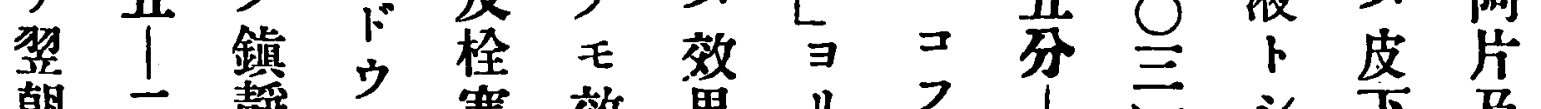

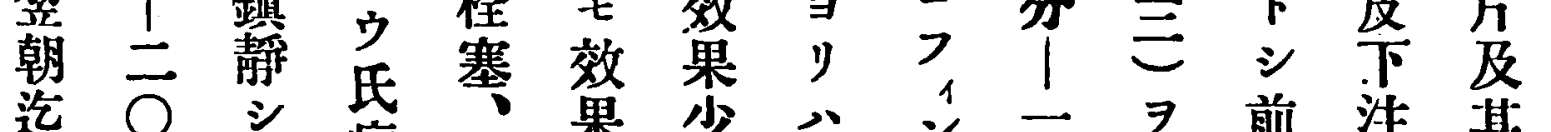
迄 $\bigcirc$ 滴 恢 病 鉛 顯 少 持 $L$ 時 泩 者 射誘 續 $\ni$ 復 精䓯 著大續 八間 射

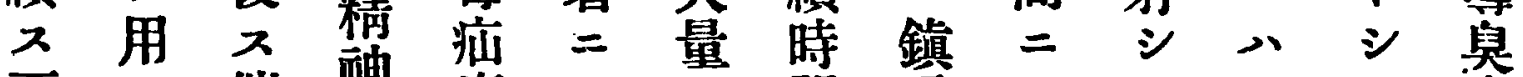

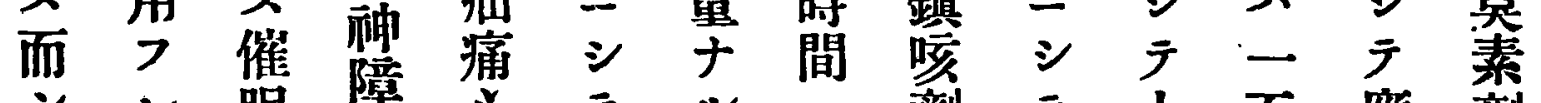

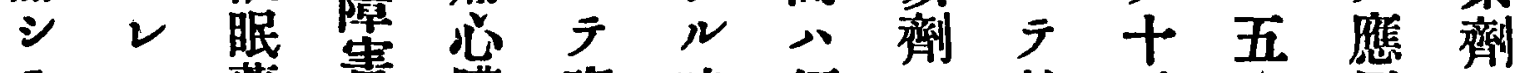
テ $心$ 藥害臟脊 時短卜效五个角及 
號 二十七百二第 空空於土 ス

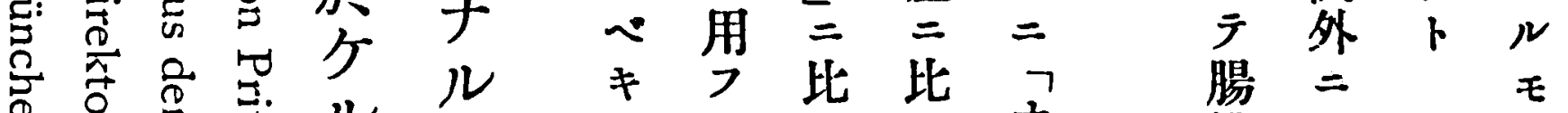

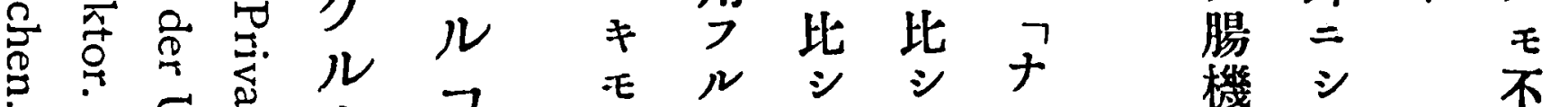

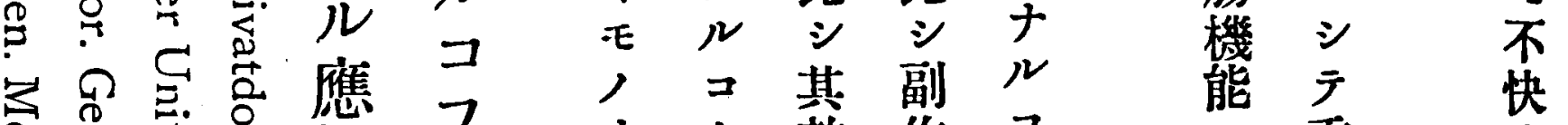

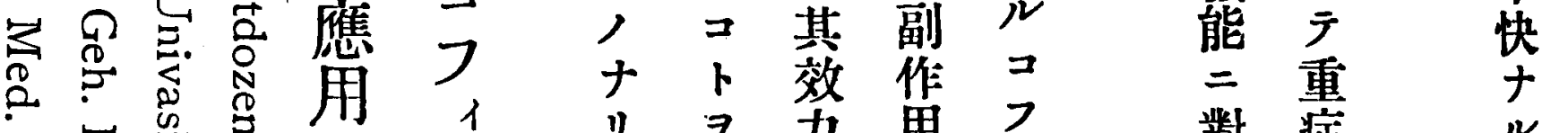

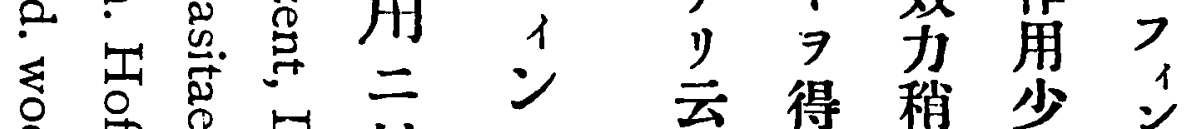

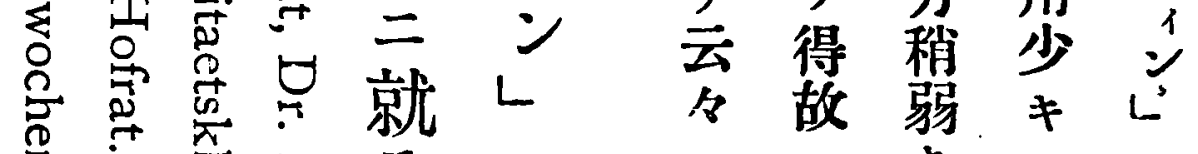

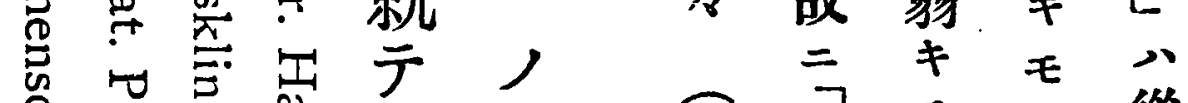

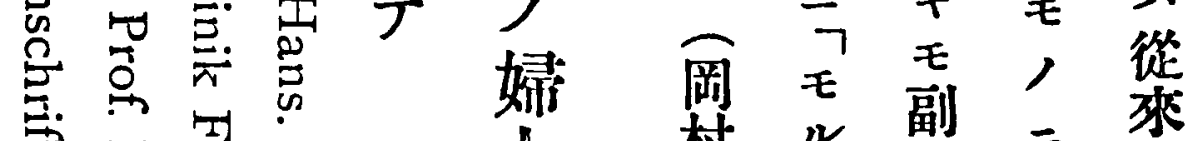

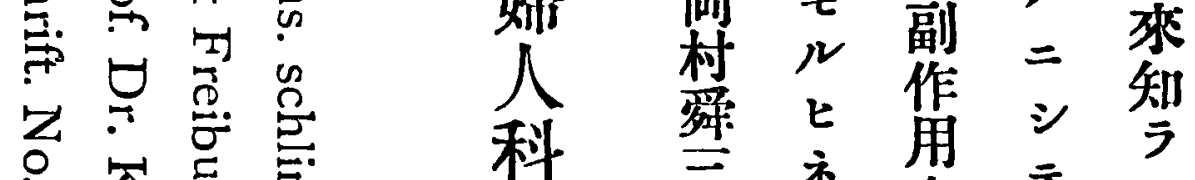

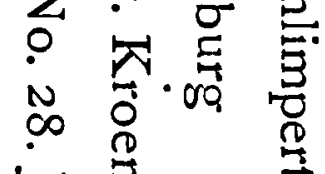

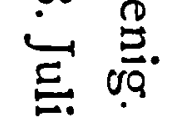
科器示角 シ ラ 學 抄, 少冏々 上

$$
\begin{aligned}
& \text { 代 = 量少 } \\
& \text { 用 } \exists=\text { 幾 } \\
& \begin{array}{ccc}
\text { 品 } & \text { テ } & \text { 罗 } \\
\text { 小 }
\end{array}
\end{aligned}
$$$$
\stackrel{\sigma}{n}
$$

對 症

シ 患副

テ 者

作

$\therefore=$ 用

蠕 乘

動 ル

$\exists モ$ 覺

緩ノノ醒

慢 = 後

ナテ 神

ラ 胃州

シ 腸 爽

么障快

害頭

婦 性一

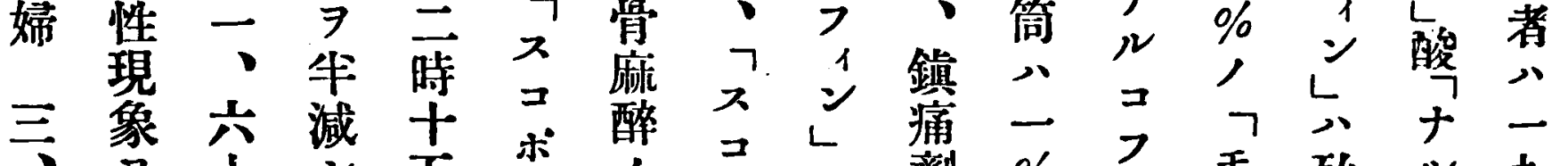
声吾

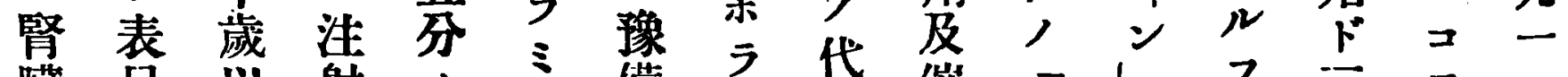

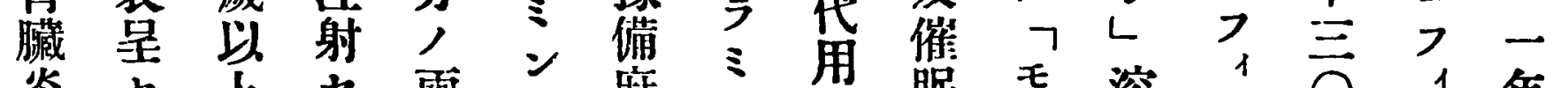
炎七上, 七 爾 レ 麻 ミ

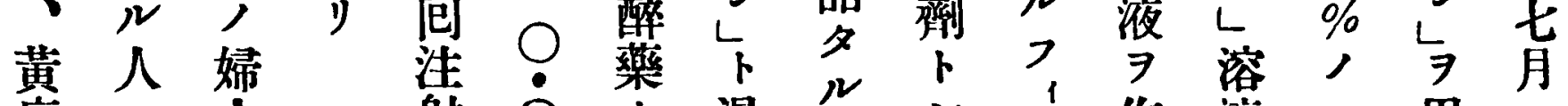

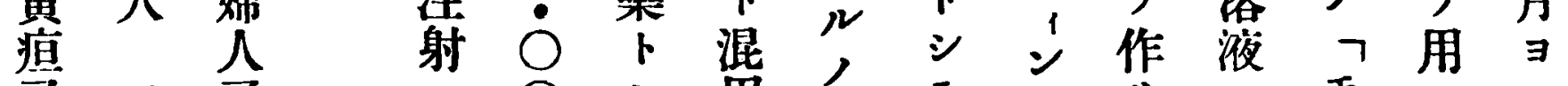

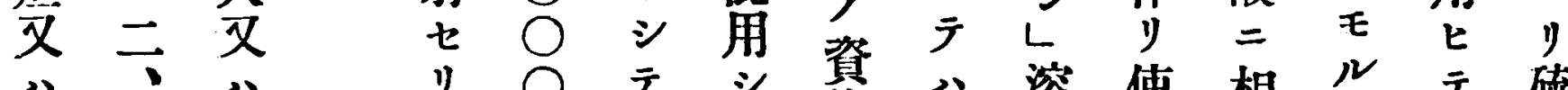

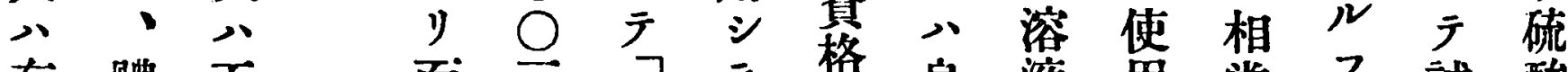

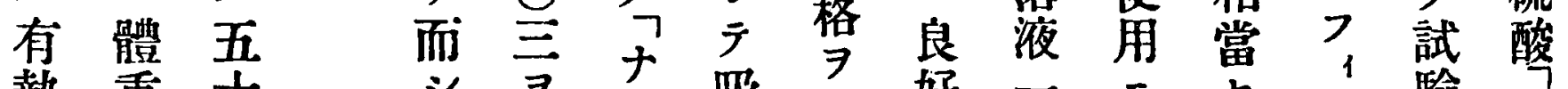
七募重 歲 囱 婦 $\bigcirc$ 占 左術 7 麻 士四永上走始 惡 以 液 $下=$ 時

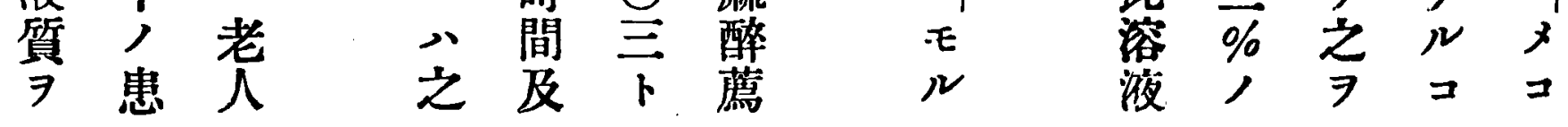




\section{號 二十七百二第}

二用千用, 倘 比入危速發來卜 シル險三スフ 定價副表ルさナ 不值作 $レ$ 卢 變ア用バ崌フ

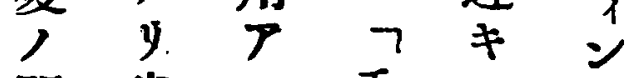

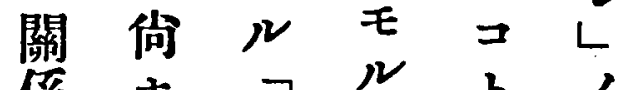
俰木フ尓卡， 二フモフ十ナ缺 於ナ ル

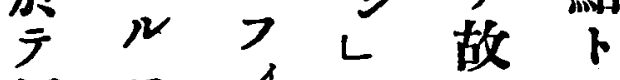
優 V ᄀ ᄂ リ ᄀ $\sim \stackrel{1}{2}$ 勝

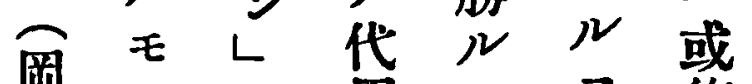

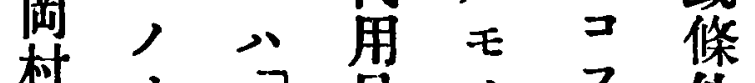
舞 , ? 品, ᄀ

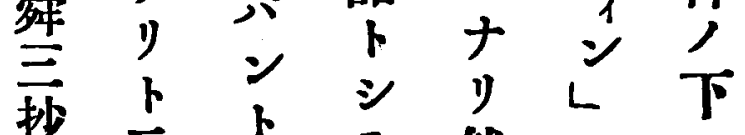
瑟去占产然只 各公基麻 亡 常 卜 作醉
二 = 、 当麻 万而

疼麻监醉 る 險痛醉七方杏次心 ナ麻力りテうノ患

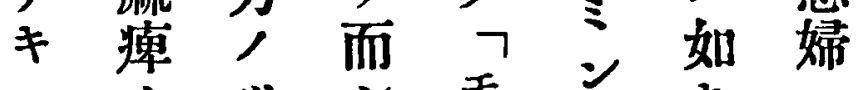

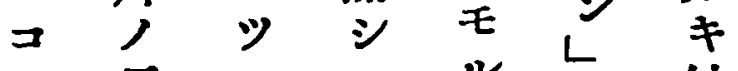

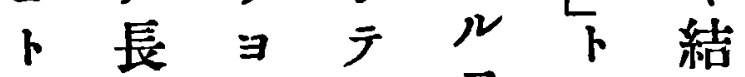
殊 クフフ十 共 果

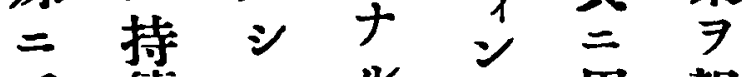
呼 續テル上用報 吸 シ 意 コ 及フ 告 中且識 樞高 二度比 ᄂ 及与較,

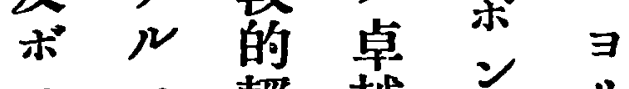
スコ輕越じリ 影卜度七こ手 響的勝術 少溷點 2 少濁 $=\quad 2 \quad \forall$ 的

呈ノル酸シ $コ ル$ 著知命用近 七共 7 素生 》患者亏兔 入時

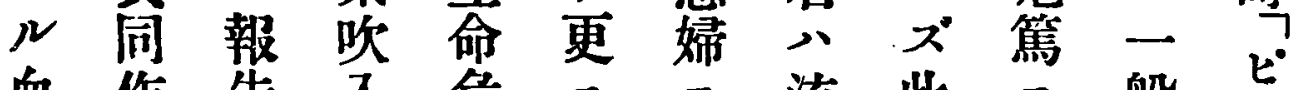
血作告 入危 三 流此三般

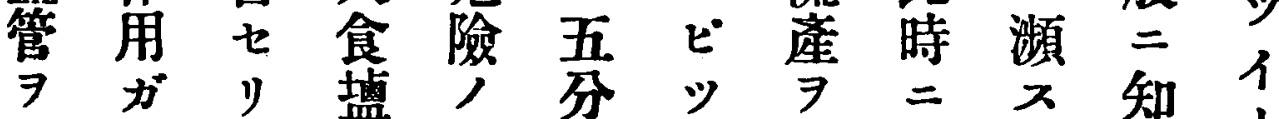

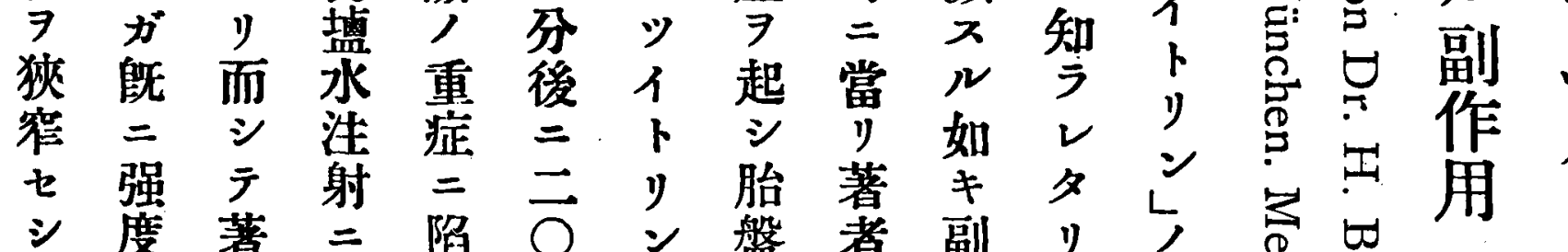

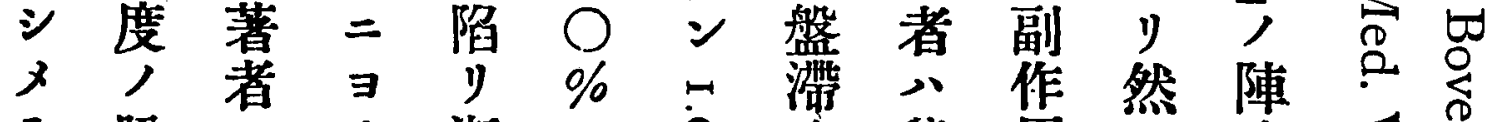

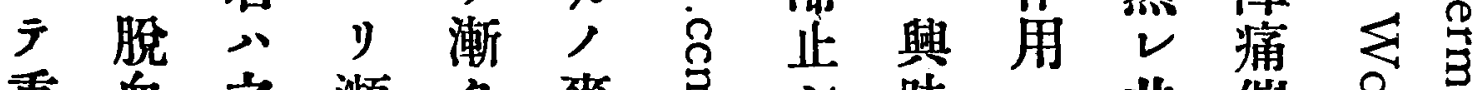

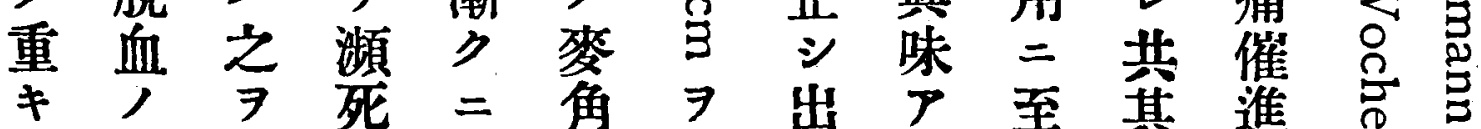

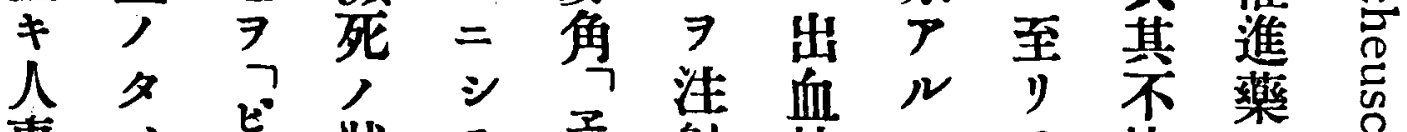
事 く

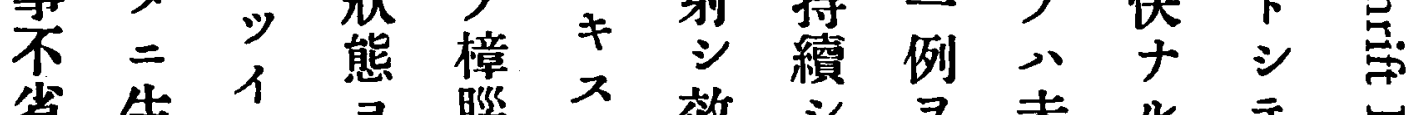

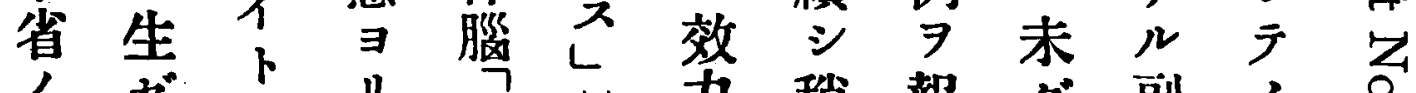

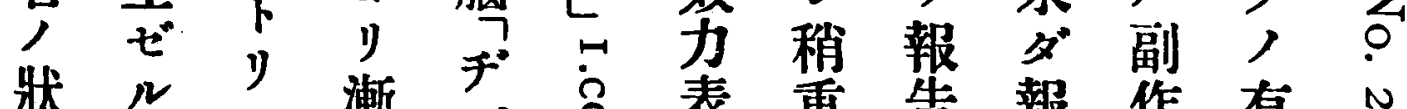

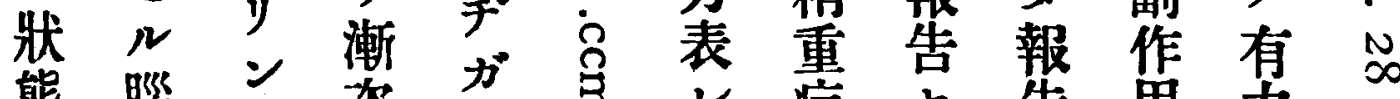

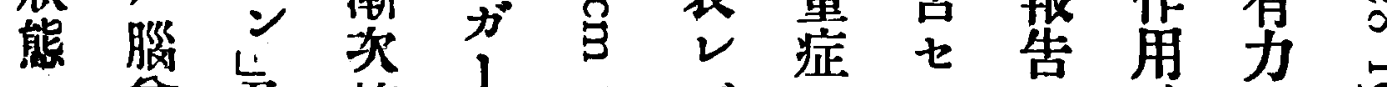

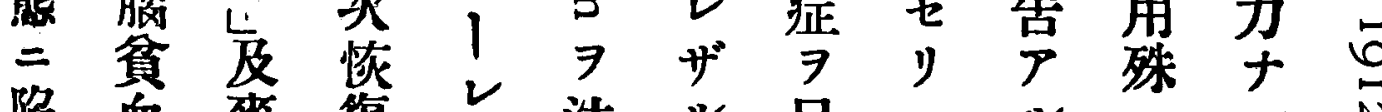
陷血零復

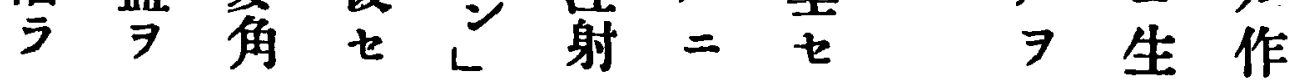


デ| 反セ結 著二然血

ル之心果切者陷

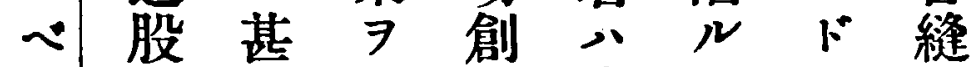

\%靜困得 $\exists$ 内如 $モ$ 合

卜脉難 v 治 頸 $\neq$ 大法

氏古ナ瘾静危血八

術サ サ

非ナ 栓 シ 觉

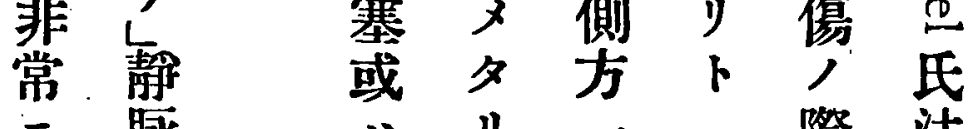

二 脉

好 開

結 口

果 部

7 .

得 靜

著 結

者 節

八,

例重

例 症

$=$ '

就 際 八y- 際 法

血只方縫最

栓、五

$\exists$ 紫

㖰方

出法乎

" 八

然動

2 胀

後瘤儿

行 $=$ ᄂ

ジ, 長

卜 好鲴
合 良

,

代

y $\bar{y}$

二 其

此 術

結 式

紮 單

法 純

カ

壤

㾴 $\begin{array}{ll}\text { ズ 者 シ } & \text { 云 } \\ \text { タ } & \text { シ } \\ & \text { ピ }\end{array}$

监

合

法

端

$=$

其

臨

呀

雍
网 $\%$

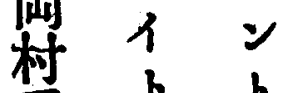

舜

抄 ᄂ 明

r

麥 故

角 =

，吾

混人

用 八

八 腒

禁 血

忌

七重

ザ 症

ル

可 $N$

今 患
應及ト尿少 シ 演

筩消、病本治者

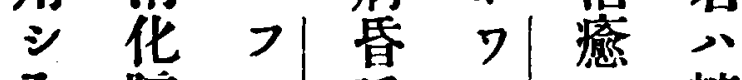

全障 ン 睡

快碍クノデタ尿

シ $・$ 二 $ン$ 病

タ前ケ例 バト

》駱水 $=$

トシ ン 就么

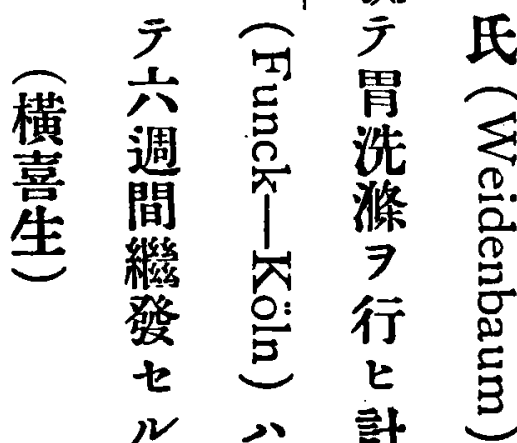

蘔糖計

棩尿 ズ 最

患 病 $€$ 近

著者輕二

$=$ 二快重

之於 七

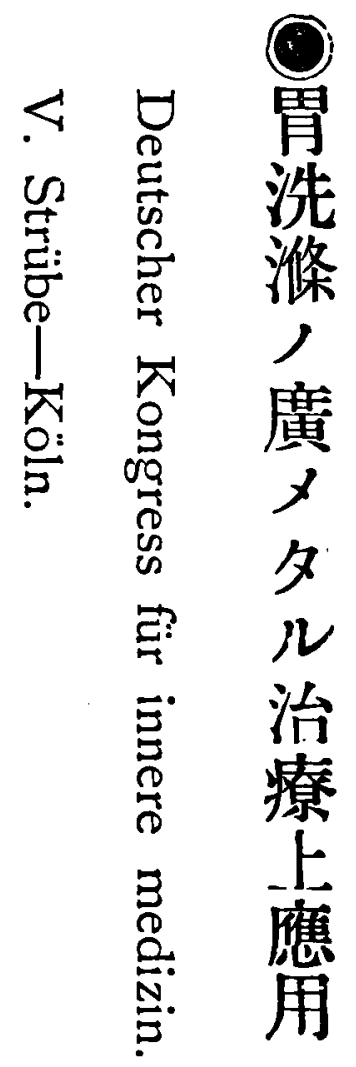

術管 之

橫 $\Rightarrow$ 化 應

丙行性筩

生 八壇 七

ข疽 》

$=$ r

八場

一 合

二 当

除

外

多

\&

不菩

結 电

果 動

二 静

終 灰 


\section{號 二十七百二第}

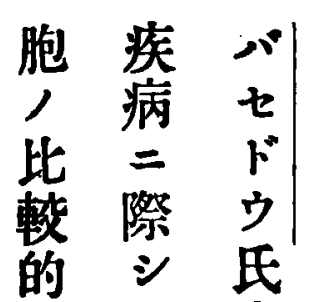

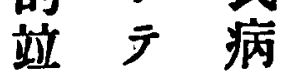
血, 絕 液 ミ 對 ノナ 的 形 $\overline{ }$ 增 態 加變 他 $\exists$ 花, 見: 品 䄪單 腺 其 核 年 細 T 數胞垂 二殊 體 於 二 方 淋 副 白巴㱗 血細,
二用穴平梅

就七?抗毒

テリ 抵 患

二侀 邑力者

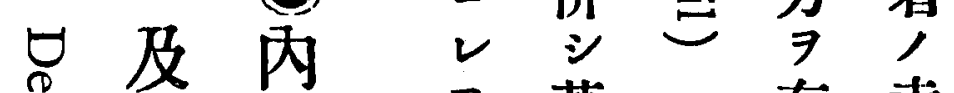

胸分 $\exists$ 著 $八$ 有赤

㤐腺泌 試 者些七血

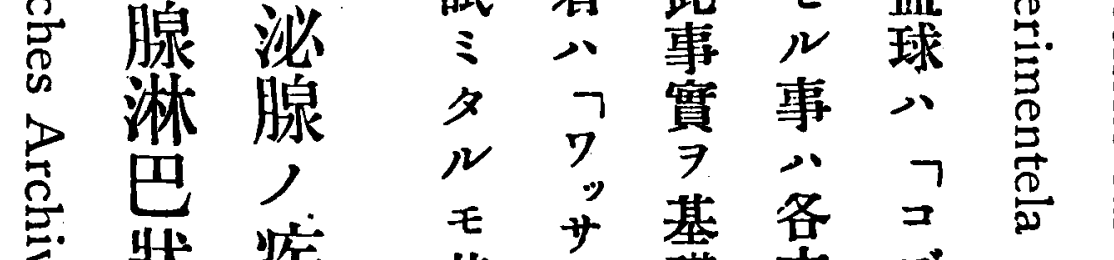

菱

五態 病

T

敢.

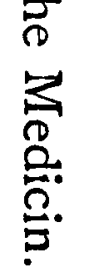

俰

關 石

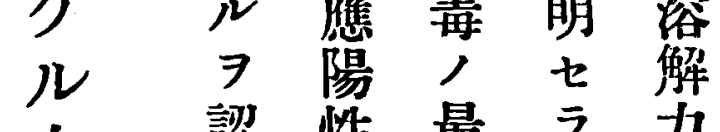

血認性最う力

液上点可對

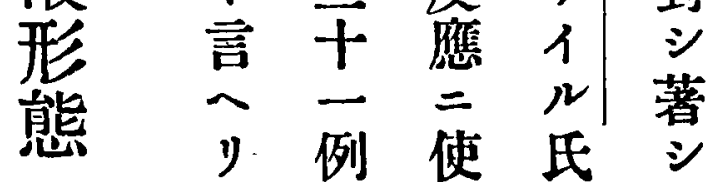

例使 氏
體 梅

욜. 赤 毒

血 馀

害球 呟

吾 抵

害热

量効 复

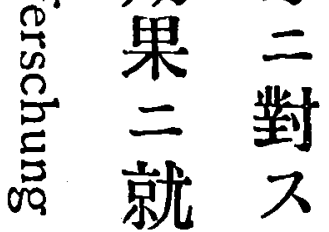

言テル

\section{䩶 \\ 罪 气 \\ 病空 \\ 獸 忽}

京

血 都

清 誌醫

中言科

$=x$ 大

於 學

ケ等 病

ル, 理

補 轍 學

體 $\Rightarrow$ 教

結 踏 室

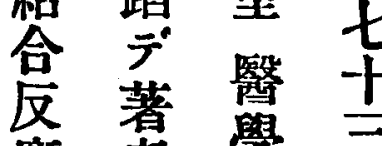

㗂 者 學

研㝵田

究本中

住 正

テ血 治

一吸述
卜 顯 淋 態 在 數 是 狀 球

八 巴

思口體關 ル場 前患少

八此 質 係 ガ 合 記 者

v場, ス 故二甲，屢

ズ 合 症 $ル$ 於 狀 血恏

卜胸狀モ凡腺液工

言腺分, テ臨主中方

人遺 其 斯 牃下=

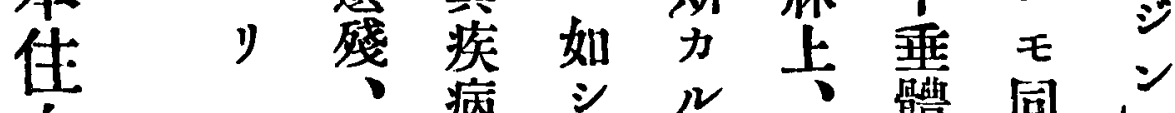

血的生病場解闹細

吸橫稹初合剖副變胞

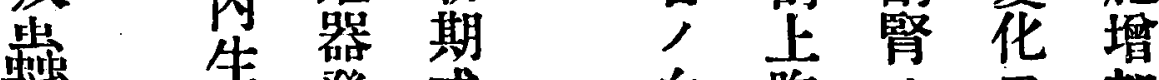

病生簦或血胸, $>$ 加

病 亩液腺疾りア

獸

ノ

IIII

清

反
不 其

金 經

二 過

因中

ス

始

.E
阌 淋 病

化巴

$\rightarrow$ 狀

胸態 y

腺, 天

淋 徵

巴 標 其

狀 確 多

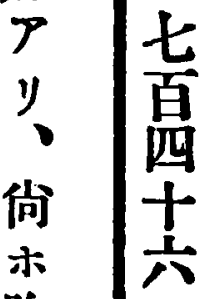

胸

腺

淋 
メ而テ罹 時 體 フ種 ルニ度 テシ】病日結杲類 $ォ$ シ 確 此後 $\exists$ 合本三發 テ 䍜

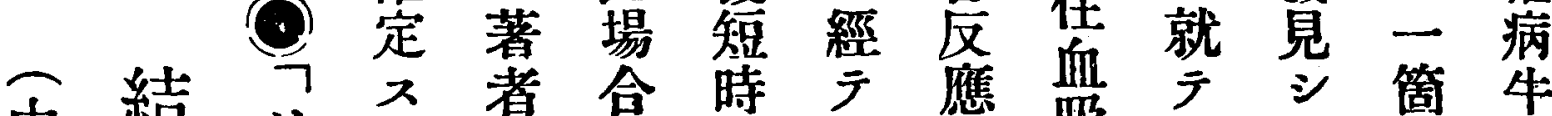

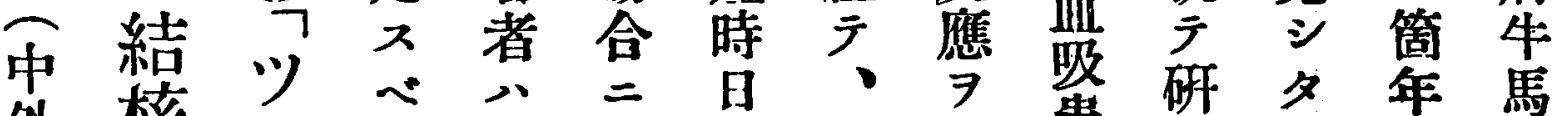
大外核べキ之於經始呈品究》年馬 阪翳、菌儿者, 於縎始呈抽究》餘二 府事儿者壬テ過

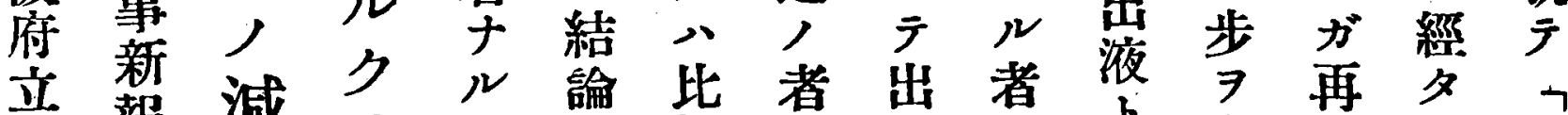

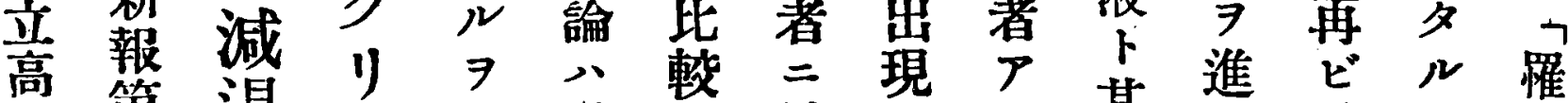
等第退 $ン$ 明猶的於

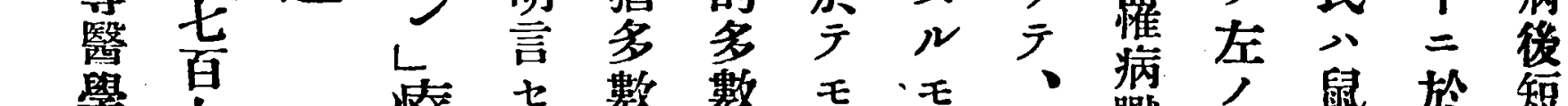

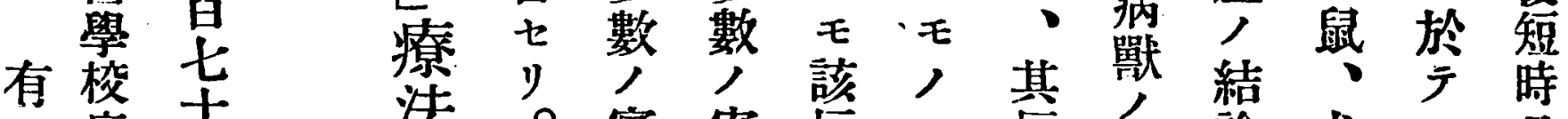

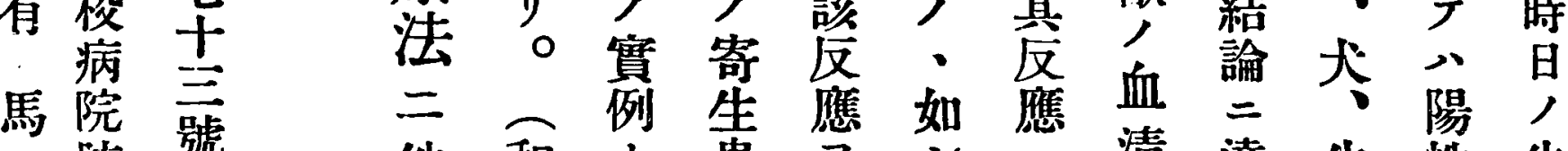
賴 瘦

吉 科

述

件和 1 蟲 $\ni$ 江清 ᄀ泉 研 7 呈 血. $\stackrel{2}{\Rightarrow} \stackrel{2}{*}$ 然病間 中抄積 夕者 $ト$ 省 初 ᄂ ${ }^{\circ}$ 文定補
牛性 牛 反 馬 馬 應 及 7 F 猿呈 八 八陰 五 ᄂ 性

\section{否ナ}

菌ノ數者一豆 ル

八結三人研 混

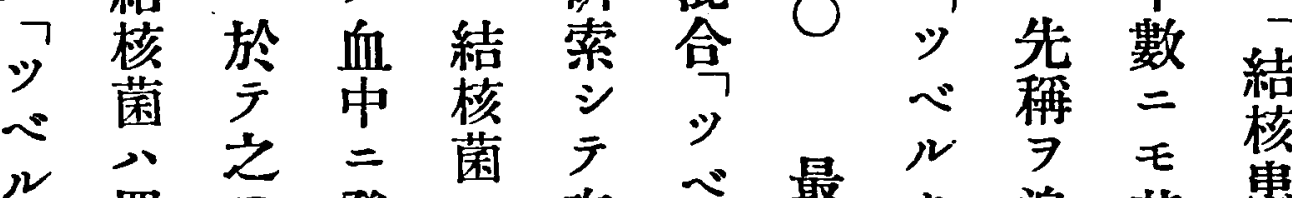

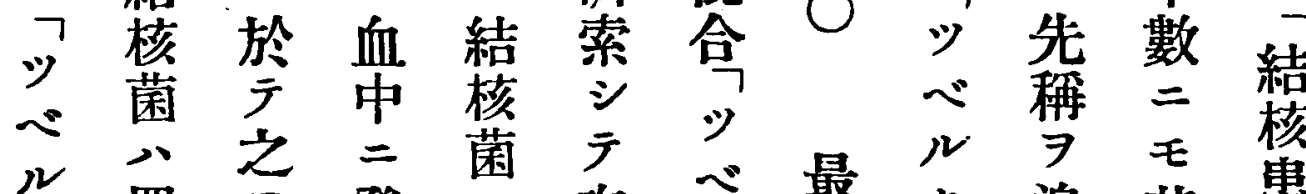

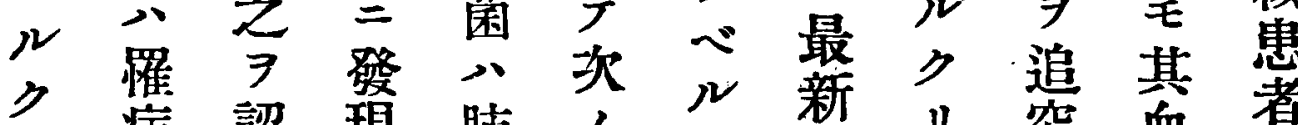

病認現肺, 媇り究血者

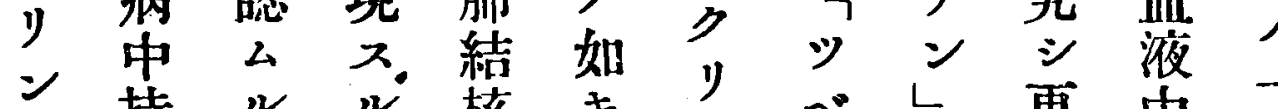

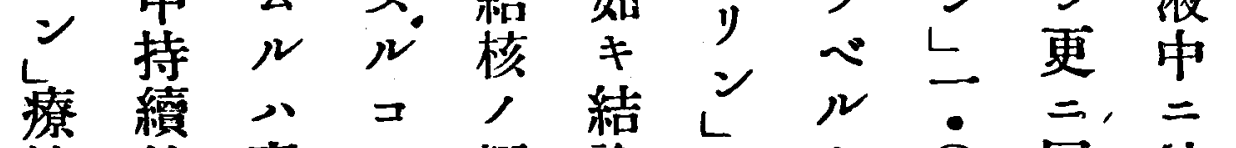

, 法的事卜極論 $\ni \Rightarrow \bigcirc$ 同結

$=$ 二實 7 × 用り 教核

依存于得 $テ$ 達 $七$ ン 室菌 \%

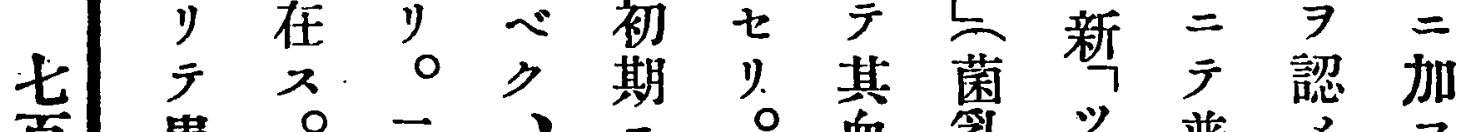

百患 ○二、”。血乳 $\%$ 普

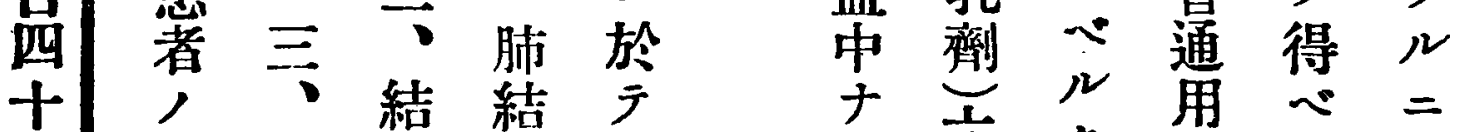

七人、結 結 テ

一血 核 核 $モ$

般 中 患患 帟

狀, 著者能

態結 血, ク

, 核中 全 患
ル 六》フ

同 $○ リ ル レ$ 謂

菌 テ テ 健

等 7 康
有テン大 焦又し 阪 氏 我 療 高 八國 法 醫 實 $=$, 二於研於 其 ケ究 驍 ル 佐 將，當 實 多 夕該 二 博 り研旦士 ○究本 7 , 醫 中 界心 害於 营 ケ × 少 二光 相 彩 當二 ス。シ 


\section{號 二十七百二第}

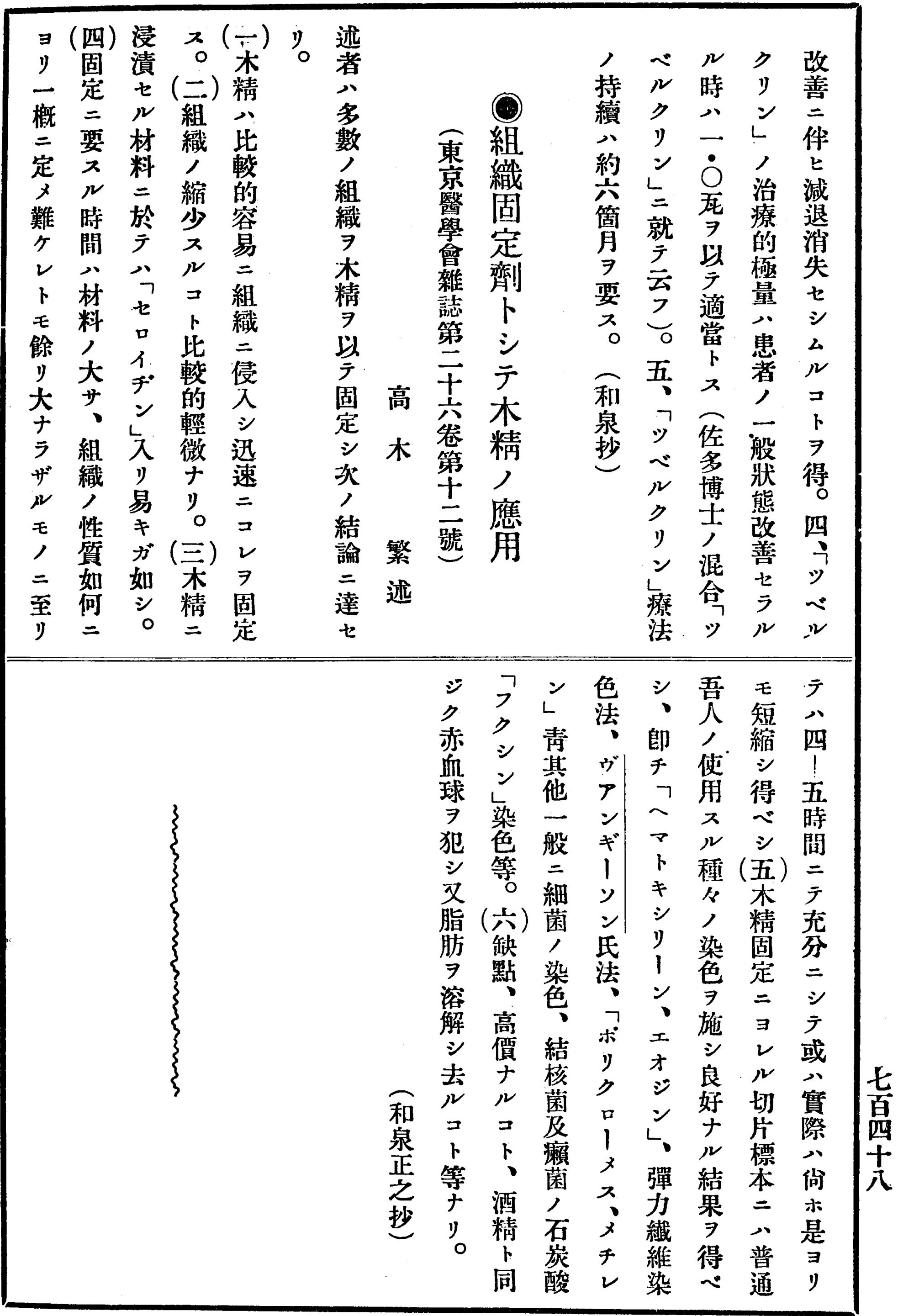

